\title{
Crop-ecology and nutritional variability influence growth and secondary metabolites of Stevia rebaudiana Bertoni
}

\author{
Probir Kumar Pal ${ }^{1 *}$, Rajender Kumar², Vipan Guleria ${ }^{3}$, Mitali Mahajan $^{1}$, Ramdeen Prasad $^{4}$, Vijaylata Pathania $^{1}$, \\ Baljinder Singh Gill ${ }^{2}$, Devinder Singh², Gopi Chand ${ }^{5}$, Bikram Singh ${ }^{1}$, Rakesh Deosharan Singh ${ }^{5}$ \\ and Paramvir Singh Ahuja ${ }^{6}$
}

\begin{abstract}
Background: Plant nutrition and climatic conditions play important roles on the growth and secondary metabolites of stevia (Stevia rebaudiana Bertoni); however, the nutritional dose is strongly governed by the soil properties and climatic conditions of the growing region. In northern India, the interactive effects of crop ecology and plant nutrition on yield and secondary metabolites of stevia are not yet properly understood. Thus, a field experiment comprising three levels of nitrogen, two levels of phosphorus and three levels of potassium was conducted at three locations to ascertain whether the spatial and nutritional variability would dominate the leaf yield and secondary metabolites profile of stevia.

Results: Principal component analysis (PCA) indicates that the applications of $90 \mathrm{~kg} \mathrm{~N}, 40 \mathrm{~kg} \mathrm{P}_{2} \mathrm{O}_{5}$ and $40 \mathrm{~kg} \mathrm{~K}_{2} \mathrm{O}$ $\mathrm{ha}^{-1}$ are the best nutritional conditions in terms of dry leaf yield for CSIR-IHBT (Council of Scientific and Industrial Research- Institute Himalayan Bioresource Technology) and RHRS (Regional Horticultural Research Station) conditions. The spatial variability also exerted considerable effect on the leaf yield and stevioside content in leaves. Among the three locations, CSIR-IHBT was found most suitable in case of dry leaf yield and secondary metabolites accumulation in leaves.

Conclusions: The results suggest that dry leaf yield and accumulation of stevioside are controlled by the environmental factors and agronomic management; however, the accumulation of rebaudioside-A (Reb-A) is not much influenced by these two factors. Thus, leaf yield and secondary metabolite profiles of stevia can be improved through the selection of appropriate growing locations and proper nutrient management.
\end{abstract}

Keywords: Stevia rebaudiana, Secondary metabolite, Crop ecology, Plant nutrition, Spatial variability, Cytokinin

\section{Background}

Stevia (Stevia rebaudiana Bertoni), a perennial herb of the Asteraceae family and native to South America (Paraguay and Brazil), is widely grown for its sweet leaf. Stevia is being commercially cultivated in Japan, China, Brazil, Paraguay, Mexico, Russia, Indonesia, Korea, USA, India, Tanzania, Canada and Argentina [1-3]. Though China is the largest stevia producer in the World market, Japan and Korea are the main consumers [4]. The worldwide

\footnotetext{
* Correspondence: palpk@ihbt.res.in

${ }^{1}$ Natural Product Chemistry and Process Development Division, Council of Scientific and Industrial Research-Institute of Himalayan Bioresource Technology (CSIR-IHBT), Post Box No. 6, Palampur 176 061HP, India Full list of author information is available at the end of the article
}

researches in connection with stevia have mainly focused on the sweet-tasting diterpenoid steviol glycosides (SGs), which are used as a non-sucrose and non-caloric sweetener in a wide range of food products. In stevia, the SGs are mainly accumulated within its leaves, followed by stems, seeds and roots [5]. Amongst the known SGs, the most abundant glycoside in stevia leaf is stevioside, which is about 300 times sweeter than sucrose [6]. RebaudiosideA (Reb-A), the second most abundant compound, is better suited than stevioside for use in foods and beverages due to its pleasant taste $[7,8]$. Thus there is a big challenge for agronomists and plant breeder to maintain the desirable level of Reb-A/ stevioside ratio in stevia leaves. 
The worldwide demand for stevia is steadily increasing, since worldwide main regularity authorities (European Food Safety Authority, The US Food and Drug Administration, The Joint FAO/WHO Expert Committee on Food Additives, Food Standards Australia New Zealand) have approved the use of SGs, extracted from stevia leaves, as a dietary supplement [9-12]. To meet the burgeoning demand of stevia, it is imperative to increase the production through vertical as well as horizontal approaches. However, the understanding the growth behaviour, accumulation patterns of secondary metabolites and nutrient uptake dynamics in different agro-climatic conditions are prerequisite for introducing a new crop in a particular region.

The variability of SGs accumulation pattern in leaves during ontogeny of stevia is considerably influenced by the cultivar variations [5], photoperiod [13,14], temperature [15] and available nutrients $[3,16]$. It has also been reported that the leaf biomass and the concentration of active compounds depend upon the growing conditions and agronomic practices [17]. Among the agronomic practices, reliable nutrient supply is the most important factor for higher crop yield. Among the 17 essential plant nutrients, N, P and K are the most often limiting macronutrients for plant growth and development. Nitrogen is an essential element of key macromolecules such as proteins, nucleic acids, some lipids, and chlorophylls $[18,19]$. Phosphorus is also a component of nucleic acids, phospholipids, and ATP [20]. Potassium, third most essential macronutrient of plant, plays a central role in many fundamental metabolic processes, such as turgor driven movements, osmoregulation, control of membrane polarization and protein biosynthesis [21]. Thus, plants cannot perform properly without a reliable supply of these nutrients. Moreover, high dose fertilizer mainly $\mathrm{N}$ is harmful for soil health, especially when applied above the economic optimum dose.

The climatic factors are equally responsible for determining the vegetative growth and secondary metabolites of stevia. Stevia is an obligate short-day (SD) plant with a critical day length of about $12 \mathrm{~h}$ [22]. Under long-day (LD) condition, the vegetative growth phase of SD plant is retained for long time by prohibiting precocious flowering. It was reported that the $\mathrm{LD}$ conditions significantly increased leaf biomass and stevioside content in stevia leaves [13,23]. Therefore, the stevia plant should be grown under LD conditions to obtain greater leaf biomass with higher stevioside content. Nevertheless, under natural conditions, LD generally happens during the summer, and during this time other abiotic factors such as temperature and solar irradiance are generally not ideal for field production of stevia [23].

Thus, it is clear that standardization of nutritional doses particularly N, P and $\mathrm{K}$ for different agro-climatic conditions is essential for increasing the biomass yield and secondary metabolites of stevia. The sole and interaction effects of N, P and $\mathrm{K}$ on leaf yield and secondary metabolites of stevia have not been systematically investigated so far under different climatic conditions of northern India. The optimum doses of $\mathrm{N}, \mathrm{P}$ and $\mathrm{K}$ for higher leaf yield under different agroclimatic conditions in India are not known. The synergistic and antagonistic effects of N, P, and K on stevia are also unknown. Thus, the objectives of this study were to (i) investigate the sole and interaction effects of N, P and K on yield, and the SGs' accumulation in leaves; and (ii) standardize of $\mathrm{N}, \mathrm{P}$ and $\mathrm{K}$ doses under different agro-climatic conditions.

\section{Methods}

\section{Experimental location, climate and soil characteristics}

The investigations were carried out during 2010 and 2011 growing seasons, at three experimental locations. The sites were experimental farm of CSIR-Institute of Himalayan Bioresource Technology (CSIR-IHBT), Palampur; Regional Horticultural Research Station (RHRS), Jachh and Agronomy research farm of Punjab Agricultural University (PAU), Ludhiana. The sites were selected based on the variability of agro-climatic conditions and soil characteristics. According to the USDA soil taxonomy classification system the soils of Palampur, Jachh, and Ludhiana belong to Alfisols [24], Entisols [25], and Inceptisols [26], respectively. The details of geophysical situation, soil characteristics and weather conditions during the investigating years are presented in the Table 1 and Figure 1.

\section{Plant material, application of treatments and crop management}

The record of cropping scheme indicated that during 2009 , the preceding year of field experimentation, stevia was grown for general purpose during spring season and remained fallow during winter. For transplanting the stevia seedlings the land was ploughed two times by power tiller to bring the good tilth of soil, and finally the land was leveled manually. Seventy-five-days-old stevia seedlings were transplanted at the end of 14th meteorological standard week (MSW) at Palampur in 2010, whereas at Jachh and Ludhiana the seedlings were transplanted at the starting of 15th MSW. In 2011, seedlings were transplanted during 13th MSW at all three locations. The planting geometry was a square shape with the space of $45 \mathrm{~cm} \times 45 \mathrm{~cm}$. The sizes of plots were $10 \mathrm{~m}^{2}(4 \times 2.5 \mathrm{~m})$. Forty five plants were accommodated in each plot. The experiment was laid out as three factors factorial arrangement in randomized block design (RBD) with three replications. Eighteen treatment combinations comprising three levels of $\mathrm{N}\left(\mathrm{N}_{1}=30 \mathrm{~kg} \mathrm{ha}^{-1}\right.$, $\mathrm{N}_{2}=60 \mathrm{~kg} \mathrm{ha}^{-1}$ and $\mathrm{N}_{3}=90 \mathrm{~kg} \mathrm{ha}^{-1}$ ), two levels of $\mathrm{P}$ $\left(\mathrm{P}_{1}=20 \mathrm{~kg} \mathrm{P}_{2} \mathrm{O}_{5} \mathrm{ha}^{-1}\right.$ and $\left.\mathrm{P}_{2}=40 \mathrm{~kg} \mathrm{P}_{2} \mathrm{O}_{5} \mathrm{ha}^{-1}\right)$ and three levels of $\mathrm{K}\left(\mathrm{K}_{1}=20 \mathrm{~kg} \mathrm{~K}_{2} \mathrm{O} \mathrm{ha}^{-1}, \mathrm{~K}_{2}=40 \mathrm{~kg} \mathrm{~K} \mathrm{~K}_{2} \mathrm{O}\right.$ $\mathrm{ha}^{-1}$ and $\mathrm{K}_{3}=60 \mathrm{~kg} \mathrm{~K}_{2} \mathrm{O} \mathrm{ha}{ }^{-1}$ ) were tested. A half quantity of $\mathrm{N}$ and full quantity of $\mathrm{P}$ and $\mathrm{K}$ as per treatment 
Table 1 Physico-chemical properties of soil and Geophysical positioning of the experimental sites

\begin{tabular}{|c|c|c|c|c|c|c|}
\hline \multirow[t]{2}{*}{ Parameter } & \multicolumn{2}{|l|}{ CSIR-IHBT } & \multicolumn{2}{|l|}{ RHRS } & \multicolumn{2}{|l|}{ PAU } \\
\hline & 2010 & 2011 & 2010 & 2011 & 2010 & 2011 \\
\hline Soil type & Silty clay & Silty clay & Loamy sand & Loamy sand & Sandy loam & Sandy loam \\
\hline $\mathrm{pH}(1: 2.0)$ & 6.40 & 5.70 & 7.50 & 7.42 & 7.82 & 7.74 \\
\hline Organic carbon (\%) & 1.98 & 1.36 & 0.70 & 0.75 & 0.26 & 0.30 \\
\hline Available nitrogen ( $\mathrm{g} \mathrm{kg}^{-1}$ soil) & 0.136 & 0.147 & 0.118 & 0.116 & 0.54 & 0.61 \\
\hline Available phosphorus ( $\mathrm{g} \mathrm{kg}^{-1}$ soil) & 0.027 & 0.025 & 0.006 & 0.007 & 0.009 & 0.008 \\
\hline Available potassium ( $\mathrm{g} \mathrm{kg}^{-1}$ soil) & 0.207 & 0.205 & 0.080 & 0.083 & 0.107 & 0.109 \\
\hline Altitude ( $\mathrm{m}$ from msl) & 1393 & 1393 & 431 & 431 & 247 & 247 \\
\hline Longitude & $\begin{array}{l}32^{\circ} 6^{\prime} 47^{\prime \prime} \mathrm{N} \text { and } \\
76^{\circ} 33^{\prime} 46^{\prime \prime} \mathrm{E}\end{array}$ & $\begin{array}{l}32^{\circ} 6^{\prime} 47^{\prime \prime} N \\
\text { and } 76^{\circ} 33^{\prime} 46^{\prime \prime} \mathrm{E}\end{array}$ & $\begin{array}{l}32^{\circ} 16^{\prime} \mathrm{N} \text { and } \\
75^{\circ} 51^{\prime}\end{array}$ & $\begin{array}{l}32^{\circ} 16^{\prime} \mathrm{N} \text { and } \\
75^{\circ} 51^{\prime}\end{array}$ & $\begin{array}{l}30^{\circ} 56^{\prime} \mathrm{N} \text { and } \\
75^{\circ} 52^{\prime} \mathrm{E}\end{array}$ & $\begin{array}{l}30^{\circ} 56^{\prime} \mathrm{N} \text { and } \\
75^{\circ} 52^{\prime} \mathrm{E}\end{array}$ \\
\hline
\end{tabular}

were applied at the time of transplanting, while the remaining half quantity of $\mathrm{N}$ was applied into two equal doses at 30 and 60 days after transplanting (DAT). The $\mathrm{N}$, $\mathrm{P}$ and $\mathrm{K}$ were applied through urea $(46 \% \mathrm{~N})$, single super phosphate $\left(16 \% \mathrm{P}_{2} \mathrm{O}_{5}\right)$ and muriate of potash $\left(60 \% \mathrm{~K}_{2} \mathrm{O}\right)$, respectively.

\section{Growth data and yield}

For growth observation, two plants were randomly selected from centre of each plot then cut at $15 \mathrm{~cm}$ height from the ground level at 1st harvest (120 DAT), and both the plants were marked with an aluminum tag for the next observation during 2nd harvest (165 DAT). During second observation roots were removed from 0 to $25 \mathrm{~cm}$ soil layer for N, P and K analysis. After removal of plants from the field, leaves were separated from stem. Total number of branches (primary and secondary) per plant was quantified. The total area of fresh leaves under respective treatments was measured using a leaf-area meter (AM 300, ADC Bio-scientific Ltd., UK). Then the leaf area was expressed in the leaf area index (LAI). After recording the fresh weight of aboveground (during both harvest) and below-ground (only at 2nd harvest) parts, the samples were dried at $70 \pm 2{ }^{\circ} \mathrm{C}$ in an oven until a constant weight was attained to calculate the percentage of dry matter (DM) accumulation. These dry samples were also used for the estimation of $\mathrm{N}, \mathrm{P}$ and $\mathrm{K}$ contents in different parts of the plant.

For determination of leaf and stem yield (fresh and dry), ten representative stevia plants from each plot were harvested at $15 \mathrm{~cm}$ height from the ground level during 1 st harvest, whereas during 2 nd harvest plants were cut at the ground level. Then the dry leaf and the stem yield from each plot were calculated by multiplying the fresh weight with factors, which are calculated from growth observation samples.

\section{Chlorophyll (Chl) determination}

For the determination of chlorophyll (Chl), the leaves were collected from each experimental unit at the time of 1st harvesting at Palampur. The major veins were removed from the collected leaf samples to reduce the error. Then $200 \mathrm{mg}$ fresh leaf sample was separated from each sample, and finally Chl was extracted in a solution of $80 \%$ acetone (v/v). Subsequently, the absorbances of the samples at 645 and $663 \mathrm{~nm}$ were recorded with a spectrophotometer (model T $90+\mathrm{UV} /$ vis, PG Instrument Ltd.). Finally, the fractions of Chl $a$, Chl $b$ and total Chl ( $\mathrm{mg} \mathrm{g}^{-1}$ tissue) were estimated from the absorbance values as per standard equations recommended by Arnon [27].

\section{Determination of NPK in plant parts and soil analysis}

Spatial and temporal dynamic of N, P and K uptake during the crop cycle were investigated lucidly for Palampur conditions. After recording growth data, representative samples of dry leaf, stem and root were prepared with a laboratory grinder having a sieve spacing of $0.7 \mathrm{~mm}$ to determine $\mathrm{N}, \mathrm{P}$ and $\mathrm{K}$ partitioning in different parts. Prepared plant samples were digested with concentrated $\mathrm{H}_{2} \mathrm{SO}_{4}$ and selenium ( $\mathrm{Se}$ ) mixture as per the procedure suggested by Sahrawat et al. [28]. Total $\mathrm{N}$ was evaluated by micro-Kjeldahl method, while total $\mathrm{P}$ and $\mathrm{K}$ were estimated through a spectrophotometer (model T $90+\mathrm{UV} /$ vis, PG Instrument Ltd.) and a flame photometer (model BWB XP, BWB technologies UK Ltd., UK) respectively, according to Prasad et al. [29].

After harvesting, soil samples were collected from the surface layer $(0-15 \mathrm{~cm})$ for determination of $\mathrm{pH}$, organic carbon $(\mathrm{OC})$, available $\mathrm{N}(\mathrm{AN})$, available $\mathrm{P}(\mathrm{AP})$ and available $\mathrm{K}(\mathrm{AK})$. The $\mathrm{pH}$ of soil water suspension $(1: 2 \mathrm{w} / \mathrm{v})$ was measured by $\mathrm{pH}$ meter (model Eutech Instruments $\mathrm{pH} 510$ ), whereas the soil OC was determined by using the standard dichromate oxidation method of Nelson and Sommers [30]. Available N status of the soil was estimated after distilling the sample with alkaline potassium permanganate solution followed by titration [31]. Bray and Kurt $\mathrm{P}_{1}$ [32] method was used for estimation of available $\mathrm{P}$, since the soil was acidic in nature. Available $\mathrm{K}$ in the soil was estimated by using 


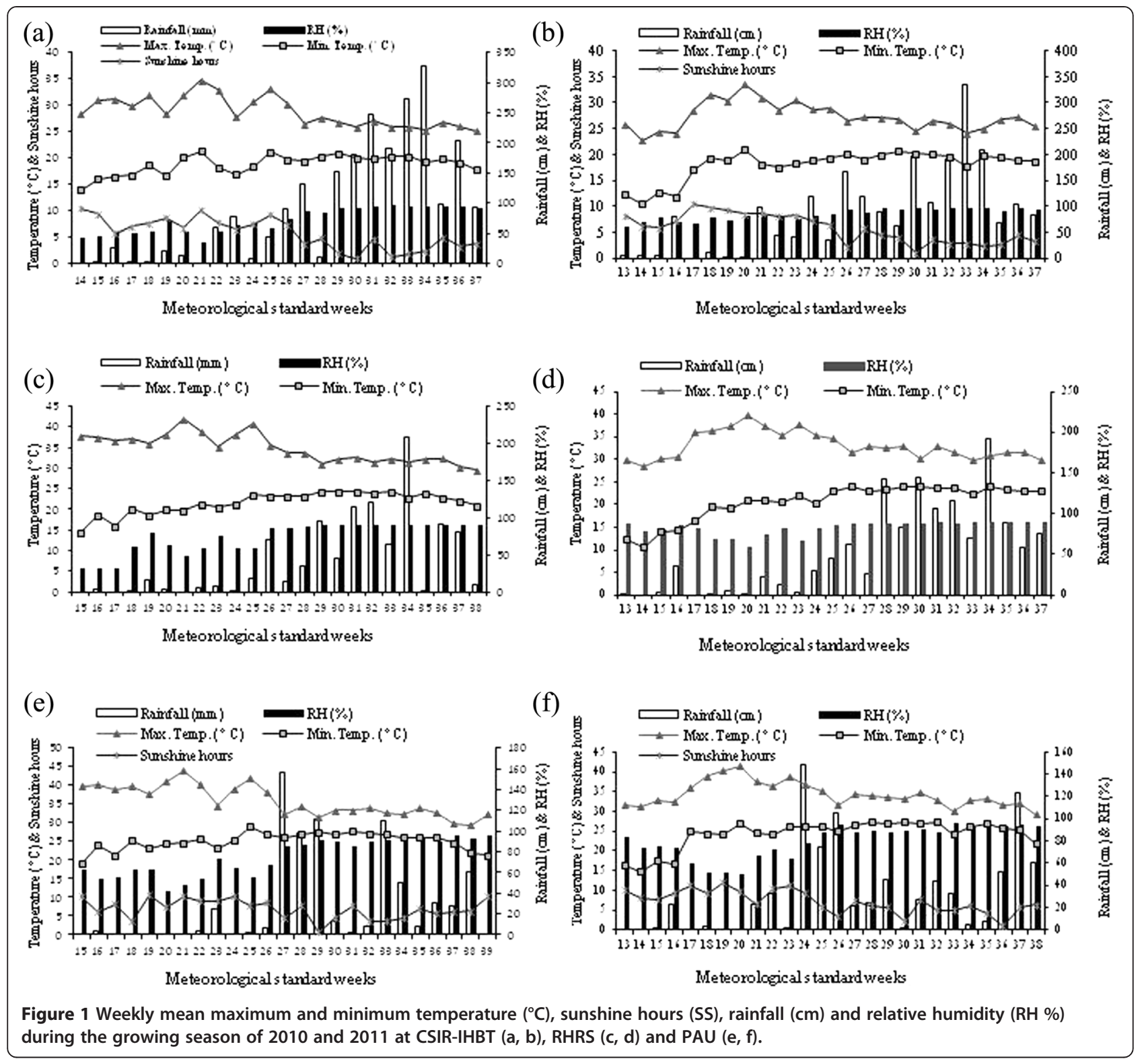

earlier mentioned model of flame photometer after Mehlich-3 [33] extraction.

\section{Extraction and analysis of steviol glycosides}

For estimation of steviol glycosides for all three locations, the leaves were collected from the middle portion of the plants from each plot at the time of harvest. The collected leaf samples were washed under running tap water to ensure the dust and microbes free samples. After removal of water from surface of the leaves, the samples were dried in a hot air oven at $40 \pm 2^{\circ} \mathrm{C}$ until constant weight was attained. Then stevioside and Reb-A were determined with the help of Waters HPLC (996 Photodiode Array Detector) system. The extraction method and HPLC conditions were followed as described in our earlier paper [3]. The fractions of stevioside and Reb-A were quantified by the means of calibration curves, which were obtained from standard stevioside and Reb-A samples.

\section{Statistical analysis}

All of the data obtained from three locations for 2 consecutive years were subjected to analysis of variance (ANOVA) using Statistica 7 software (Stat Soft Inc., Tulsa, Oklahoma, USA). The three-factors-factorial ANOVA was carried out separately for each year to estimate the variance components of main $(\mathrm{N}, \mathrm{P}$ and $\mathrm{K})$ effects and their reciprocal interactions $(\mathrm{N} \times \mathrm{P}, \mathrm{N} \times \mathrm{K}, \mathrm{P} \times \mathrm{K}$ and $\mathrm{N} \times \mathrm{P} \times \mathrm{K})$ effects. Differences among the treatments were assessed with the least significant difference (LSD) only when the ANOVA $F$-test showed significance at $P=0.05$. The data 
on secondary metabolites were presented as mean \pm standard error $(\mathrm{SE})$, and student paired $t$-test $(P=0.05)$ was applied to separate the treatment means. Principal component analysis (PCA) was also used to evaluate the nature of variation among the treatment combinations as a bi-plot. Factor loading values, which are presented as vectors, are the correlations of each variable (LAI, number of branches, leaf yield, stem yield, $\mathrm{Chl}$ and secondary metabolite profile) with the principal component (PC).

\section{Results}

\section{Yield attributes}

The analyzed data (Table 2) revealed that two main yieldattributes of stevia, number of branches $\left(\right.$ No. Plant $\left.{ }^{-1}\right)$ and LAI, were significantly affected by the level of $\mathrm{N}$ particularly at 1st harvest during both the years. During 1st harvesting stage, the maximum number of branches (7.58 and 11.86 No. plant ${ }^{-1}$ ) was registered with $\mathrm{N}_{3}$, that is significantly $(P \leq 0.05)$ different from $\mathrm{N}_{1}$, in both the experimental years, and from $\mathrm{N}_{2}$ in 2010. The effect of $\mathrm{N}_{3}$ and $\mathrm{N}_{2}$ on LAI at 1st harvest and total LAI were significantly higher compared with the effect of $\mathrm{N}_{1}$; however, these two treatments are statistically at par in both the years. The LAI at 2nd harvest was almost equal under all the treatments during both the years. At 1st harvest, the number of branches was significantly $(P \leq 0.05)$ affected by $P$ during 2010 , and highest number (6.64 No. plant ${ }^{-1}$ ) was recorded with $\mathrm{P}_{2}$. On the other hand, LAI at 1st harvest and total LAI were significantly $(P \leq 0.05)$ affected by the level of $P$, and the maximum LAI was recorded with $\mathrm{P}_{2}$ in both the years.

The effect of $\mathrm{K}$ on the number of branches was not significant $(P \geq 0.05)$ at 1 st harvest; however, the maximum number of branches (6.64 and 11.53 No. plant-1) was recorded with $K_{2}$ and $K_{3}$ during 2010 and 2011, respectively. Among the $\mathrm{K}$ levels, the maximum LAI at 1st harvest and total LAI were recorded with $K_{3}$ and $K_{2}$ in 2010 and 2011, respectively, and these two treatments were significantly $(P \leq 0.05)$ different from $K_{1}$. Though the SLW of stevia during 1st harvest was not significantly $(P \geq 0.05)$ influenced by the level of NPK doses, the marginal improvement of SLW was observed

Table 2 Effect of different levels $\mathrm{N}, \mathrm{P}$ and $\mathrm{K}$ on yield attributes of stevia under CSIR-IHBT conditions

\begin{tabular}{|c|c|c|c|c|c|c|c|c|c|c|c|c|c|c|}
\hline \multirow[t]{3}{*}{ Treatment } & \multicolumn{4}{|c|}{ Total branches (No plant ${ }^{-1}$ ) } & \multicolumn{6}{|c|}{ Leaf area index(LAI) } & \multicolumn{4}{|c|}{ Specific leaf weight $\left(\mathrm{mg} \mathrm{cm}^{-2}\right)$} \\
\hline & \multicolumn{2}{|c|}{ At 1st harvest } & \multicolumn{2}{|c|}{ At 2nd harvest } & \multicolumn{2}{|c|}{ At 1st harvest } & \multicolumn{2}{|c|}{ At 2nd harvest } & \multicolumn{2}{|c|}{ Total LAI } & \multicolumn{2}{|c|}{ At 1st harvest } & \multicolumn{2}{|c|}{ At 2nd harvest } \\
\hline & 2010 & 2011 & 2010 & 2011 & 2010 & 2011 & 2010 & 2011 & 2010 & 2011 & 2010 & 2011 & 2010 & 2011 \\
\hline \multicolumn{15}{|l|}{ Nitrogen Level } \\
\hline $\mathrm{N}_{30}$ & 5.29 & 9.06 & 18.29 & 23.5 & 1.41 & 1.67 & 0.22 & 0.2 & 1.63 & 1.88 & 7.47 & 7.54 & 7.64 & 9.33 \\
\hline $\mathrm{N}_{60}$ & 6.63 & 10.97 & 22.94 & 26.61 & 1.71 & 2.03 & 0.26 & 0.24 & 1.97 & 2.27 & 7.46 & 7.82 & 11.38 & 9.25 \\
\hline $\mathrm{N}_{90}$ & 7.58 & 11.86 & 25.34 & 27.72 & 1.77 & 2.12 & 0.27 & 0.25 & 2.04 & 2.37 & 7.43 & 8.39 & 14.75 & 9.97 \\
\hline $\operatorname{SEm}( \pm)$ & 0.30 & 0.52 & 0.83 & 1.77 & 0.04 & 0.04 & 0.02 & 0.013 & 0.05 & 0.04 & 0.27 & 0.67 & 0.89 & 0.75 \\
\hline$C D(P=0.05)$ & 0.86 & 1.50 & 2.38 & NS & 0.11 & 0.12 & NS & NS & 0.13 & 0.13 & NS & NS & 2.56 & NS \\
\hline \multicolumn{15}{|l|}{ Phosphorus Level } \\
\hline$P_{20}$ & 5.97 & 10.41 & 21.31 & 25.54 & 1.59 & 1.89 & 0.24 & 0.22 & 1.83 & 2.1 & 7.43 & 7.76 & 11.06 & 9.79 \\
\hline$P_{40}$ & 7.03 & 10.85 & 23.07 & 26.35 & 1.68 & 2.00 & 0.26 & 0.24 & 1.91 & 2.25 & 7.59 & 8.09 & 11.45 & 9.24 \\
\hline SEm $( \pm)$ & 0.24 & 0.43 & 0.68 & 1.45 & 0.03 & 0.03 & 0.01 & 0.011 & 0.04 & 0.03 & 0.22 & 0.55 & 0.73 & 0.62 \\
\hline$C D(P=0.05)$ & 0.70 & NS & NS & NS & 0.09 & 10 & NS & NS & 0.11 & 0.10 & NS & NS & NS & NS \\
\hline \multicolumn{15}{|l|}{ Potassium Level } \\
\hline $\mathrm{K}_{20}$ & 6.4 & 10.06 & 20.29 & 25.28 & 1.56 & 1.82 & 0.22 & 0.23 & 1.78 & 2.05 & 7.19 & 7.39 & 11.13 & 9.15 \\
\hline $\mathrm{K}_{40}$ & 6.46 & 11.53 & 24.11 & 26.97 & 1.61 & 2.04 & 0.25 & 0.24 & 1.88 & 2.27 & 7.81 & 8.07 & 12.39 & 9.72 \\
\hline $\mathrm{K}_{60}$ & 6.64 & 10.31 & 22.18 & 25.58 & 1.73 & 1.98 & 0.27 & 0.22 & 1.99 & 2.02 & 7.36 & 8.3 & 10.25 & 9.68 \\
\hline $\operatorname{SEm}( \pm)$ & 0.30 & 0.52 & 0.83 & 1.77 & 0.04 & 0.04 & 0.02 & 0.013 & 0.05 & 0.04 & 0.27 & 0.67 & 0.89 & 0.75 \\
\hline$C D(P=0.05)$ & NS & NS & 2.38 & NS & 0.11 & 0.12 & NS & NS & 0.13 & 0.13 & NS & NS & NS & NS \\
\hline \multicolumn{15}{|l|}{ Interaction effect } \\
\hline $\mathrm{CD}$ of $\mathrm{N} \times \mathrm{P}$ & NS & NS & NS & NS & NS & NS & NS & NS & NS & 0.18 & NS & NS & NS & NS \\
\hline $\mathrm{CD}$ of $\mathrm{N} \times \mathrm{K}$ & NS & NS & 2.35 & NS & NS & NS & NS & NS & NS & 0.22 & NS & NS & NS & NS \\
\hline$C D$ of $P \times K$ & NS & NS & NS & NS & NS & NS & 0.06 & NS & NS & NS & NS & NS & 3.61 & NS \\
\hline$C D$ of $N \times P \times K$ & NS & NS & NS & NS & NS & NS & NS & NS & NS & NS & NS & NS & NS & NS \\
\hline
\end{tabular}

$N_{1}, N_{2}$ and $N_{3}$ are the level of nitrogen @ 30,60 and $90 \mathrm{~kg} \mathrm{ha}^{-1}$, respectively. $P_{1}$ and $P_{2}$ are the level of phosphorus $\left(P_{2} \mathrm{O}_{5}\right) @ 20$ and 40 kg ha ${ }^{-1}$, respectively, while $K_{1}, K_{2}$ and $K_{3}$ are representing the level of potassium $\left(K_{2} \mathrm{O}\right) @ 20,40$ and $60 \mathrm{~kg} \mathrm{ha}^{-1}$, respectively. 
with the moderate level of $\mathrm{N}$ and $\mathrm{K}\left(\mathrm{N}_{2}\right.$ and $\left.\mathrm{K}_{2}\right)$ and higher level of $\mathrm{P}$.

\section{Leaf yield, stem yield and harvest index $(\mathrm{HI})$}

The data presented in Table 3 showed that the performance of stevia in terms of dry leaf yield $\left(\mathrm{t} \mathrm{ha}^{-1}\right)$ was superior under CSIR-IHBT conditions. Nevertheless, least performance was found under PAU conditions. The analyzed data (Table 3) also revealed that the overall effects of N, P and K on dry leaf yield $\left(\mathrm{t} \mathrm{ha}^{-1}\right)$ of stevia were significant $(P \leq 0.05)$ under CSIR-IHBT and RHRS conditions in 2010 and 2011. At PAU, dry leaf yield was not significantly affected by $\mathrm{K}$ $(P \geq 0.05)$ in both the years. Irrespective of $\mathrm{P}$ and $\mathrm{K}$ fertilization, the dry leaf yield $\left(\mathrm{t} \mathrm{ha}^{-1}\right)$ of stevia was increased with the corresponding increasing level of $\mathrm{N}$ at all 3 locations in both the years. Nevertheless, the magnitude of increase from $\mathrm{N}_{1}$ to $\mathrm{N}_{2}$ was higher compared with $\mathrm{N}_{2}$ to $\mathrm{N}_{3}$ particularly under CSIR-IHBT and PAU conditions. Under CSIR-IHBT conditions, $\mathrm{N}_{3}$ significantly $(P \leq 0.05)$ increased dry leaf yield $\left(\mathrm{t} \mathrm{ha}^{-1}\right)$ by about 36 and $42 \%$, irrespective of $\mathrm{P}$ and $\mathrm{K}$ treatments, compared with $\mathrm{N}_{1}$ during 2010 and 2011, respectively. Similarly, significantly $(P \leq$ $0.05)$ higher dry leaf yield was also recorded with $\mathrm{N}_{3}$ compared with $\mathrm{N}_{1}$ under RHRS and PAU conditions in both the years. Moreover, the effect of climatic conditions was more pronounced on dry leaf yield $\left(\mathrm{t} \mathrm{ha}^{-1}\right)$. Irrespective of $\mathrm{P}$ and $\mathrm{K}$ treatments, the maximum dry leaf yield (1.69 and $1.91 \mathrm{tha}^{-1}$ ) of stevia which was recorded with $90 \mathrm{~kg} \mathrm{~N} \mathrm{ha}^{-1}$ under CSIR-IHBT conditions, was about 62 and 164\% higher at the same level of $\mathrm{N}$ compared with RHRS and PAU, respectively, on polled basis.

The dry leaf yield in response to $\mathrm{P}$ was significant $(P \leq$ 0.05) under CSIR-IHBT and RHRS conditions and the maximum yield (Table 3) was recorded with $\mathrm{P}_{2}$ in both the years. However, the effect of $P$ in terms of dry leaf yield was not significant $(P \geq 0.05)$ at PAU in 2010. Irrespective of $\mathrm{N}$ and $\mathrm{P}$ application, the dry leaf yield $\left(\mathrm{t} \mathrm{ha}^{-1}\right)$ of stevia was significantly $(P \leq 0.05)$ affected by different levels of $\mathrm{K}$ fertilization under CSIR-IHBT and RHRS conditions in both the years. The maximum dry leaf yields of stevia under

Table 3 Effect of different levels $\mathrm{N}, \mathrm{P}$ and $\mathrm{K}$ on yield $\left(\mathrm{t} \mathrm{ha}^{-1}\right)$ and harvest index $(\mathrm{HI})$ of stevia under different experimental locations

\begin{tabular}{|c|c|c|c|c|c|c|c|c|c|c|c|c|c|c|c|c|c|c|}
\hline \multirow[t]{3}{*}{ Treatment } & \multicolumn{6}{|c|}{ Dry leaf yield (t ha ${ }^{-1}$ ) } & \multicolumn{6}{|c|}{ Dry stem yield $\left(\mathrm{t} \mathrm{ha} \mathrm{h}^{-1}\right.$ ) } & \multicolumn{6}{|c|}{ Harvest Index (HI) } \\
\hline & \multicolumn{2}{|c|}{ CSIR-IHBT } & \multicolumn{2}{|l|}{ RHRS } & \multicolumn{2}{|l|}{ PAU } & \multicolumn{2}{|c|}{ CSIR-IHBT } & \multicolumn{2}{|l|}{ RHRS } & \multicolumn{2}{|l|}{ PAU } & \multicolumn{2}{|c|}{ CSIR-IHBT } & \multicolumn{2}{|l|}{ RHRS } & \multicolumn{2}{|l|}{ PAU } \\
\hline & 2010 & 2011 & 2010 & 2011 & 2010 & 2011 & 2010 & 2011 & 2010 & 2011 & 2010 & 2011 & 2010 & 2011 & 2010 & 2011 & 2010 & 2011 \\
\hline \multicolumn{19}{|l|}{ Nitrogen Level } \\
\hline $\mathrm{N}_{30}$ & 1.24 & 1.34 & 0.79 & 0.91 & 0.39 & 0.6 & 1.83 & 1.99 & 1.42 & 1.43 & 0.78 & 1.19 & 0.41 & 0.42 & 0.36 & 0.39 & 0.34 & 0.33 \\
\hline $\mathrm{N}_{60}$ & 1.56 & 1.69 & 0.93 & 1.04 & 0.52 & 0.81 & 2.19 & 2.48 & 1.47 & 1.56 & 0.76 & 1.47 & 0.42 & 0.41 & 0.39 & 0.4 & 0.4 & 0.35 \\
\hline $\mathrm{N}_{90}$ & 1.69 & 1.91 & 1.03 & 1.19 & 0.53 & 0.83 & 2.35 & 2.65 & 1.56 & 1.69 & 0.74 & 1.53 & 0.42 & 0.42 & 0.39 & 0.41 & 0.41 & 0.35 \\
\hline SEm( $( \pm)$ & 0.04 & 0.03 & 0.03 & 0.02 & 0.02 & 0.04 & 0.04 & 0.05 & 0.03 & 0.03 & 0.03 & 0.08 & 0.007 & 0.004 & 0.009 & 0.007 & 0.007 & 0.011 \\
\hline$C D(P=0.05)$ & 0.10 & 0.09 & 0.08 & 0.06 & 0.05 & 0.13 & 0.12 & 0.14 & 0.08 & 0.08 & NS & 0.22 & NS & NS & 0.025 & NS & 0.021 & NS \\
\hline \multicolumn{19}{|c|}{ Phosphorus Level } \\
\hline$P_{20}$ & 1.44 & 1.55 & 0.87 & 1.01 & 0.47 & 0.68 & 1.94 & 2.22 & 1.48 & 1.55 & 0.73 & 1.35 & 0.42 & 0.41 & 0.37 & 0.39 & 0.39 & 0.34 \\
\hline$P_{40}$ & 1.55 & 1.74 & 0.98 & 1.08 & 0.48 & 0.8 & 2.3 & 2.52 & 1.49 & 1.56 & 0.79 & 1.45 & 0.4 & 0.41 & 0.39 & 0.41 & 0.38 & 0.35 \\
\hline SEm ( \pm$)$ & 0.03 & 0.03 & 0.02 & 0.02 & 0.01 & 0.04 & 0.03 & 0.04 & 0.02 & 0.02 & 0.03 & 0.06 & 0.006 & 0.003 & 0.007 & 0.006 & 0.006 & 0.009 \\
\hline$C D(P=0.05)$ & 0.08 & 0.07 & 0.06 & 0.05 & NS & 0.11 & 0.10 & 0.12 & NS & NS & NS & NS & 0.016 & NS & 0.020 & 0.016 & NS & NS \\
\hline \multicolumn{19}{|l|}{ Potassium Level } \\
\hline $\mathrm{K}_{20}$ & 1.38 & 1.51 & 0.84 & 0.99 & 0.47 & 0.74 & 1.91 & 2.20 & 1.49 & 1.53 & 0.75 & 1.31 & 0.41 & 0.41 & 0.37 & 0.39 & 0.38 & 0.36 \\
\hline $\mathrm{K}_{40}$ & 1.62 & 1.74 & 0.98 & 1.08 & 0.49 & 0.76 & 2.11 & 2.44 & 1.52 & 1.59 & 0.77 & 1.48 & 0.43 & 0.42 & 0.39 & 0.4 & 0.38 & 0.34 \\
\hline $\mathrm{K}_{60}$ & 1.50 & 1.69 & 0.95 & 1.07 & 0.49 & 0.73 & 2.34 & 2.48 & 1.54 & 1.56 & 0.76 & 1.41 & 0.39 & 0.41 & 0.38 & 0.4 & 0.39 & 0.34 \\
\hline SEm $( \pm)$ & 0.04 & 0.03 & 0.03 & 0.02 & 0.02 & 0.04 & 0.04 & 0.05 & 0.03 & 0.03 & 0.03 & 0.08 & 0.007 & 0.004 & 0.009 & 0.007 & 0.007 & 0.011 \\
\hline$C D(P=0.05)$ & 0.10 & 0.09 & 0.08 & 0.06 & NS & NS & 0.12 & 0.14 & 0.08 & NS & NS & NS & 0.02 & NS & NS & NS & NS & NS \\
\hline \multicolumn{19}{|c|}{ Interaction effect } \\
\hline$C D$ of $N \times P$ & NS & NS & NS & NS & NS & NS & 0.16 & 0.20 & NS & NS & NS & NS & NS & NS & NS & NS & NS & NS \\
\hline$C D$ of $N \times K$ & 0.18 & 0.16 & NS & NS & NS & NS & 0.20 & NS & NS & NS & NS & NS & 0.04 & NS & NS & NS & NS & NS \\
\hline$C D$ of $P \times K$ & NS & NS & NS & NS & NS & NS & 0.16 & NS & NS & NS & NS & NS & 0.03 & NS & NS & NS & NS & NS \\
\hline$C D$ of $\mathrm{N} \times \mathrm{P} \times \mathrm{K}$ & NS & NS & NS & NS & NS & NS & NS & NS & NS & NS & NS & NS & NS & NS & NS & NS & NS & NS \\
\hline
\end{tabular}

$N_{1}, N_{2}$ and $N_{3}$ are the level of nitrogen @ 30,60 and $90 \mathrm{~kg} \mathrm{ha}^{-1}$, respectively. $\mathrm{P}_{1}$ and $\mathrm{P}_{2}$ are the level of phosphorus $\left(\mathrm{P}_{2} \mathrm{O}_{5}\right) @ 20$ and $40 \mathrm{~kg}$ ha ${ }^{-1}$, respectively, while $\mathrm{K}_{1}, \mathrm{~K}_{2}$ and $\mathrm{K}_{3}$ are representing the level of potassium $\left(\mathrm{K}_{2} \mathrm{O}\right) @ 20,40$ and $60 \mathrm{~kg} \mathrm{ha}^{-1}$, respectively. 
CSIR-IHBT conditions were 1.62 and $1.74 \mathrm{t} \mathrm{ha}^{-1}$ during 2010 and 2011, respectively, with $40 \mathrm{~kg} \mathrm{~K} \mathrm{ha}^{-1}$. However, further increases in $\mathrm{K}$ application resulted in a decline in dry leaf yield, and the lowest value (1.38 and $\left.1.51 \mathrm{t} \mathrm{ha}^{-1}\right)$ was observed with the application of $20 \mathrm{~kg} \mathrm{~K} \mathrm{ha}^{-1}$. Among the 1st order interactions $(\mathrm{N} \times \mathrm{P}, \mathrm{N} \times \mathrm{K}$, and $\mathrm{P} \times \mathrm{K})$, the effect of $\mathrm{N} \times \mathrm{K}$ on dry leaf yield was significant under CSIRIHBT conditions, however, the 2 nd order $(\mathrm{N} \times \mathrm{P} \times \mathrm{K})$ interaction effects were insignificant $(P \geq 0.05)$ at all 3 locations (Table 3).

The analyzed data (Table 3) revealed that the effect of applied $\mathrm{N}$ on dry stem yield $\left(\mathrm{t} \mathrm{ha}^{-1}\right)$ was significant $(P \leq$ 0.05) under CSIR-IHBT and RHRS conditions in both the years. The trend of stem yield was similar to leaf yield, and the maximum stem yield $(2.35$ and $2.65 \mathrm{t}$ ha ${ }^{-1}$ ) was recorded with $\mathrm{N}_{3}$ under CSIR-IHBT conditions in both the years. Though the effects of $\mathrm{P}$ and $\mathrm{K}$ were negligible under RHRS and PAU conditions, the significant effects were found at CSIR-IHBT. The data revealed (Table 3) that the harvest index (HI) of stevia was not markedly influenced by different levels of $\mathrm{N}, \mathrm{P}$ and $\mathrm{K}$ under all 3 conditions. However, the application of $90 \mathrm{~kg} \mathrm{~N} \mathrm{ha}{ }^{-1}$ resulted in significantly $(P \leq 0.05)$ higher HI compared with $30 \mathrm{~kg} \mathrm{~N}^{-1}$ under RHRS and PAU conditions during 2010.

\section{Physical and economical optimal dose $\left(\mathrm{kg} \mathrm{ha}^{-1}\right)$}

The physical and economical optima of $\mathrm{N}$ and $\mathrm{K}$ fertilizer doses were estimated for IHBT and PAU conditions by derivation of quadratic equations, which are presented in Table 4 for the respective sites. The physical optima of $\mathrm{N}$ were 106.67 and $74.44 \mathrm{~kg} \mathrm{ha}^{-1}$ for CSIR-IHBT and PAU conditions, respectively. However, the physical optima of $\mathrm{K}$ were estimated for all 3 locations, since the yield responses were quadratic. The physical optima of $\mathrm{K}$ for CSIR-IHBT, RHRS and PAU conditions were 44.62, 39.75 and $45.00 \mathrm{~kg} \mathrm{ha}^{-1}$, respectively. Economical optima of $\mathrm{N}$ and $\mathrm{K}$ were estimated based on prevailing market price of urea (Rs. $5.50 \mathrm{~kg}^{-1}$ ), muriate of potash (Rs. $12.00 \mathrm{~kg}^{-1}$ ) and dry leaf of stevia (Rs. $130.00 \mathrm{~kg}^{-1}$ ) in India. Economical optima of $\mathrm{N}$ were very close to physical optima, which are 106.16 and $73.93 \mathrm{~kg} \mathrm{ha}^{-1}$ for CSIR-IHBT and PAU conditions, respectively. The economical optima of $\mathrm{K}$ for CSIR-IHBT, RHRS and PAU conditions were 44.43, 39.37 and $43.08 \mathrm{~kg} \mathrm{ha}^{-1}$, respectively.

\section{Regression and correlation analysis}

The correlation analysis revealed that dry leaf yield $\left(\mathrm{t} \mathrm{ha}^{-1}\right)$ was significantly $(P \leq 0.05)$ and positively correlated with total LAI with correlation coefficients of 0.83 in 2010 and 0.77 in 2011. A significant $(P \leq 0.05)$ positive correlation was also found with the number of branches at 1st harvest having correlation coefficients of 0.77 and 0.90 during 2010 and 2011, respectively. The regression between yield and yield attributes is explained by the equation of

$$
\begin{aligned}
\hat{\mathrm{Y}}= & -1.2338+0.0242 \mathrm{X}_{1}-0.0037 \mathrm{X}_{2}+0.6974^{* *} \mathrm{X}_{3} \\
& +0.1325^{* *} \mathrm{X}_{4}+0.0241^{* *} \mathrm{X}_{5}\left(\mathrm{R}^{2}=0.973^{* *}\right)
\end{aligned}
$$

Where $\hat{Y}$ is the dry leaf yield $\left(\mathrm{t} \mathrm{ha}^{-1}\right), \mathrm{X}_{1}$ the number of branches per plant at 1st harvest, $X_{2}$ the number of branches per plant at 2nd harvest, $\mathrm{X}_{3}$ the total LAI, $\mathrm{X}_{4}$ the SLW at 1st harvest, and $X_{5}$ is the SLW at 2nd harvest. The $R^{2}$ values indicated that more than $97 \%$ of the variability of dry leaf yield $\left(\mathrm{t} \mathrm{ha}^{-1}\right)$ was explained by these variables. The regression coefficients of total LAI, SLW at 1st harvest and SLW at 2nd harvest were also significant $(\mathrm{P} \leq 0.01)$.

\section{Spatial and temporal nutrient dynamic in plant}

Spatial and temporal nutrient (N, P and $\mathrm{K}$ ) dynamics of stevia under CSIR-IHBT conditions are illustrated in the Figure 2. The overall NPK accumulation patterns in response to different levels of $\mathrm{N}, \mathrm{P}$ and $\mathrm{K}$ were insignificant $(P \geq 0.05)$. However, irrespective of nutritional treatment, the considerable differences were found due to spatial and temporal variations. The highest quantity of $\mathrm{N}$ was accumulated in the leaf followed by stem and root, and the magnitude of accumulation during 1st harvest was marginally higher compared with 2nd harvest. However, the trend of $\mathrm{N}$ accumulation in the leaf was similar at both harvesting stages, and the highest magnitude was recorded

Table 4 Predictive regression equations and physical and economical optimal doses of $\mathbf{N}$ and $\mathbf{K}$ under different agro-climatic conditions

\begin{tabular}{lllll}
\hline Experimental site & Plant nutrient & Regression equation & Physical optima (kg ha ${ }^{-\mathbf{1}}$ ) & Economical optima (kg ha $^{\mathbf{- 1}}$ ) \\
\hline CSIR-IHBT & Nitrogen & $y=0.795+0.0192^{*} x-0.00009^{*} x^{2}$ & 106.67 & 106.16 \\
& Potassium & $y=0.89+0.0358^{*} x-0.0004^{*} x^{2}$ & 44.62 & 44.43 \\
RHRS & Nitrogen & $y=0.705+0.005^{*} x-0.000006^{*} x^{2}$ & - & - \\
& Potassium & $y=0.665+0.0159^{*} x-0.0002^{*} x^{2}$ & 39.75 & 39.37 \\
PAU & Nitrogen & $y=0.17+0.0134^{*} x-0.00009^{*} x^{2}$ & 74.44 & 73.93 \\
& Potassium & $y=0.55+0.0036^{*} x-0.00004^{*} x^{2}$ & 45.00 & 43.08 \\
\hline
\end{tabular}

${ }^{*}$ mark indicates that the corresponding values are significant at $P=0.05$. The physical and economical optima of $\mathrm{N}$ for RHRS were not calculated since the relation between $\mathrm{N}$ and dry leaf yield $\left(\mathrm{t} \mathrm{ha}^{-1}\right)$ was almost linear. 


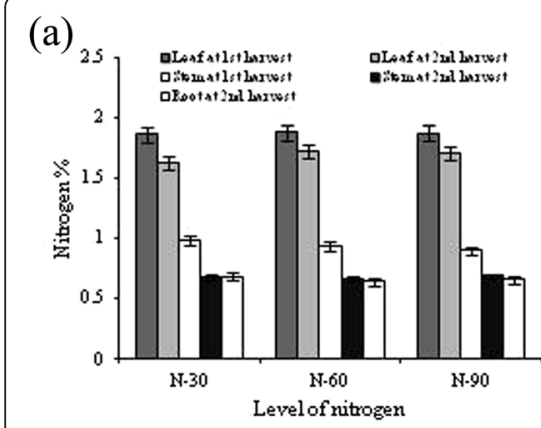

(d)

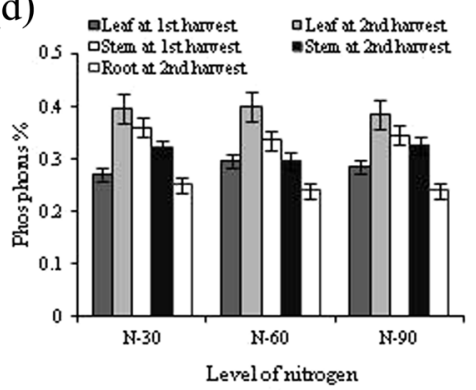

(g)

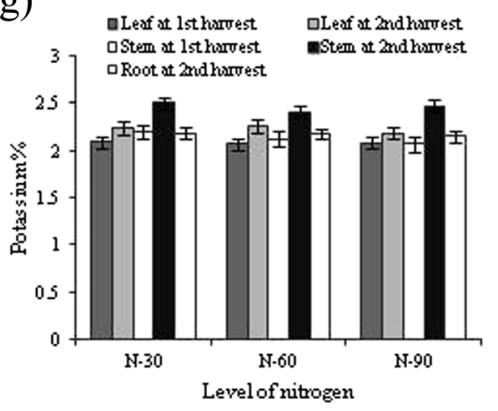

(b)

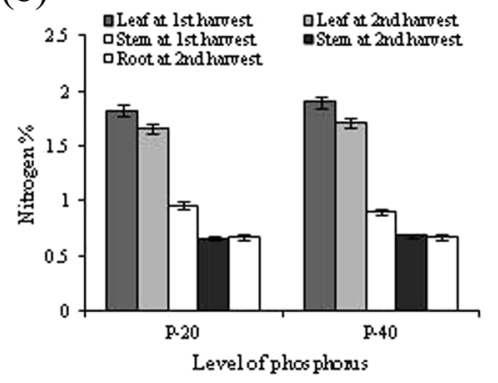

(e)

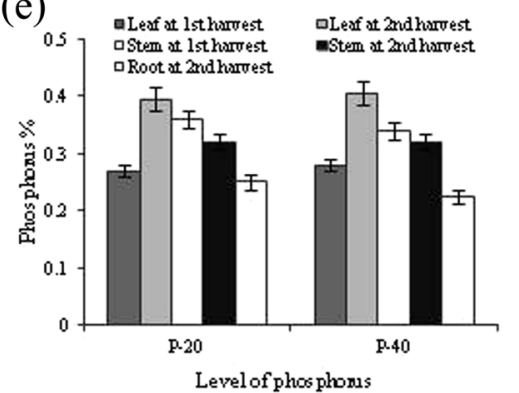

(h)

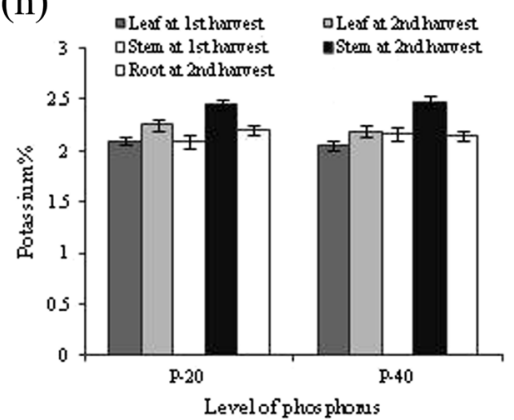

(c)

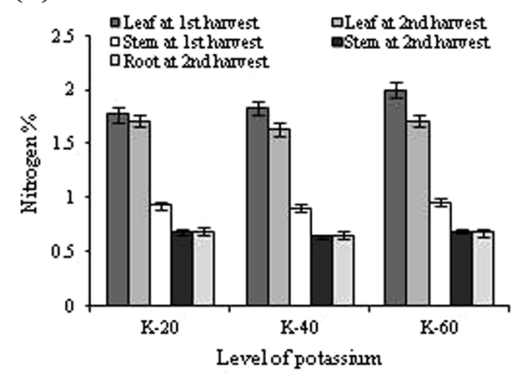

(f)

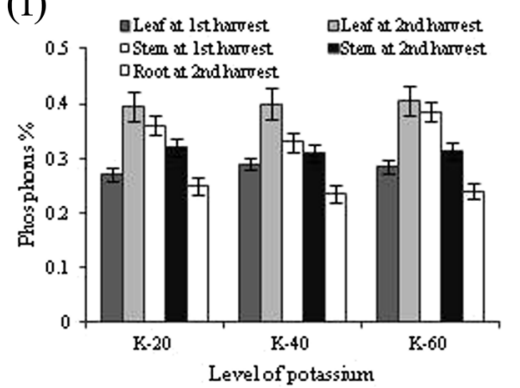

(i)

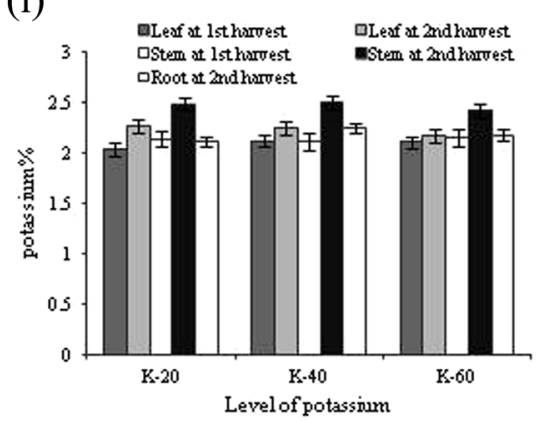

Figure 2 Spatial and temporal accumulation of $\mathrm{N}(\mathrm{a}-\mathrm{c}), \mathrm{P}(\mathrm{d}-\mathrm{f})$ and $\mathrm{K}(\mathrm{g}-\mathrm{i})$ in stevia plant as influenced by applied N, P and K at CSIR-IHBT. The mean values of two years pooled data are presented. Vertical bars indicate a mean standard error $( \pm)$.

with $\mathrm{N}_{2}$ (1.88 and $\left.1.72 \%\right), \mathrm{P}_{2}$ (1.91 and 1.71\%) and $\mathrm{K}_{3}(2.0$ and $1.71 \%)$ in the respective factors. The trend of $\mathrm{N}$ accumulation in the stem in two harvesting stages was not similar under different nutritional treatments. In contrast to $\mathrm{N}$, the accumulation of $\mathrm{P}$ in leaf was marginally higher at 2 nd harvest. Similarly, K content in leaf and stem was higher during 2nd harvesting. However, the effects of applied $\mathrm{K}$ in terms of $\mathrm{K}$ content (\%) in leaf, stem and root were inconsistent.

\section{Chlorophyll (Chl) content in leaf}

The results presented in the Figure 3 showed that the effects of N, P and K on Chl $a$ and Chl $b$ were not significant $(P \geq 0.05)$ during 2010; however, the application of higher dose of $\mathrm{N}\left(90 \mathrm{~kg} \mathrm{ha}^{-1}\right)$ significantly increased Chl $b$ content compared with low and moderate levels of $\mathrm{N}$ during 2011. Regardless of $\mathrm{P}$ and $\mathrm{K}$, the total $\mathrm{Chl}$ content in leaves was also significantly $(P \leq 0.05)$ influenced by level of $\mathrm{N}$ during 2010 and 2011(Figure 3), and the utmost
(3.45 and $3.86 \mathrm{mg} \mathrm{g}^{-1}$ ) and least (2.98 and $3.42 \mathrm{mg} \mathrm{g}^{-1}$ ) quantity were recorded with $\mathrm{N}_{3}$ and $\mathrm{N}_{1}$, respectively. Irrespective of $\mathrm{P}$ and $\mathrm{K}$ fertilization, the correlation between applied $\mathrm{N}$ and total $\mathrm{Chl}$ content was significant, with correlation coefficient of $0.99(P \leq 0.05)$ in 2010. On the other hand, $\mathrm{P}$ and $\mathrm{K}$ did not significantly $(P \geq 0.05)$ influence total Chl content.

\section{Secondary metabolites accumulation in leaf}

The two major SGs in stevia leaf, stevioside and Reb-A, which were quantified for all 3 locations, are presented in Table 5. In this study, the overall effects of N, P and $\mathrm{K}$ on stevioside and Reb-A were not considerable under RHRS and PAU conditions. Nevertheless, the effect of $\mathrm{N}$ on stevioside and total SGs (stevioside + Reb-A) was significant $(P \leq 0.05)$ under CSIR-IHBT conditions, and the maximum quantity (12.68 and $16.2 \%)$ was recorded with the application of moderate quantity of $\mathrm{N}\left(60 \mathrm{~kg} \mathrm{ha}^{-1}\right)$. This treatment recorded about 27 and $18 \%$ higher stevioside 

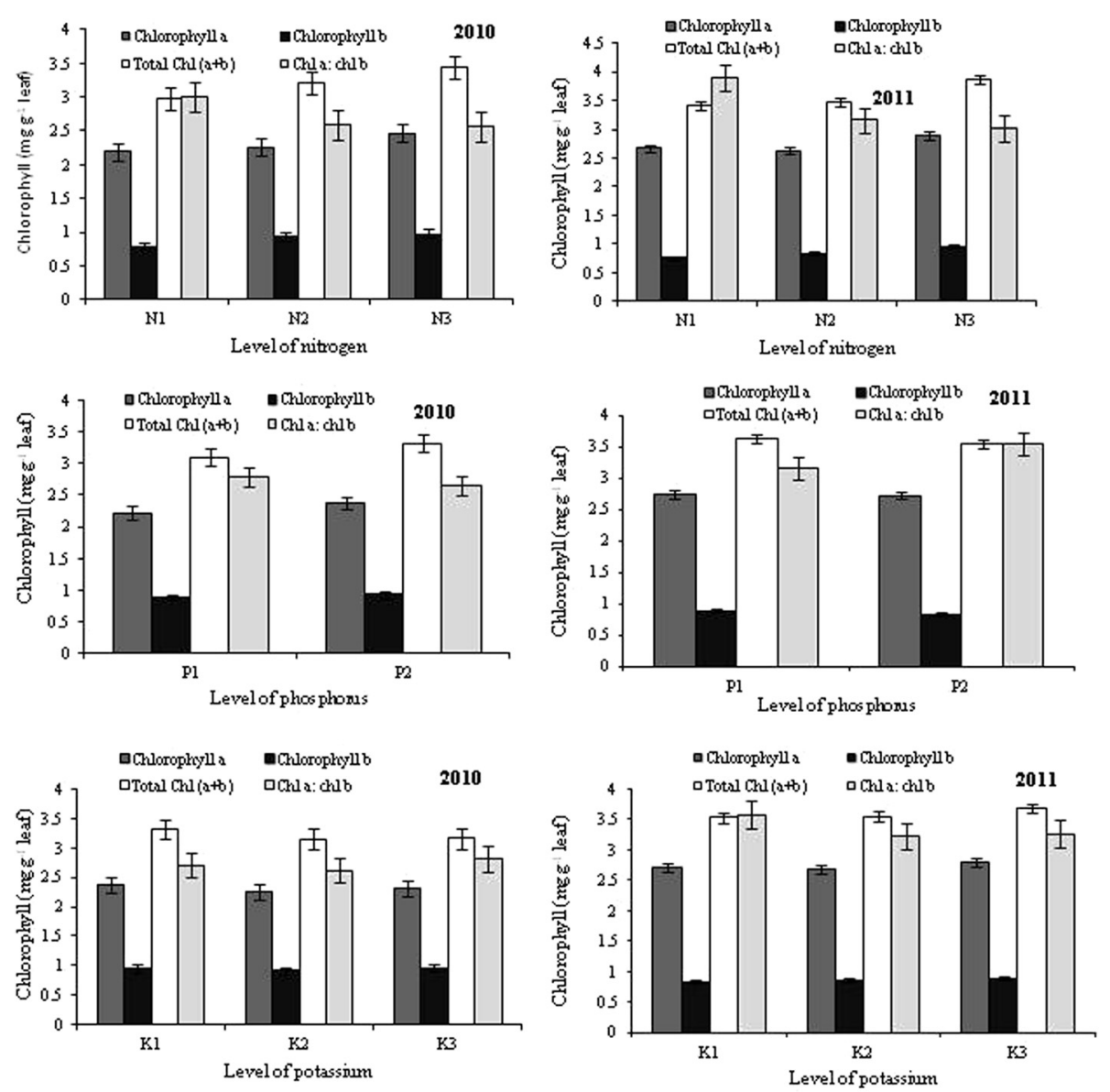

Figure 3 Photosynthetic pigments in leaves of stevia plants grown under different levels of N, P and K at CSIR-IHBT. The data represent the mean of two years. Vertical bars indicate a mean standard error $( \pm)$.

content in leaf, irrespective of $\mathrm{P}$ and $\mathrm{K}$ treatments, compared with $\mathrm{N}_{1}$ and $\mathrm{N}_{3}$, respectively. At PAU, the trend of stevioside accumulation under $\mathrm{N}$ treatments was similar to CSIR-IHBT conditions. Whereas, at RHRS, the total SGs content gradually increased with the application up to $90 \mathrm{~kg} \mathrm{~N} \mathrm{ha}^{-1}$ but statistically at par $(P \geq$ 0.05 ) with the rest of $\mathrm{N}$ treatments. In addition, it was clear that the variations in stevioside accumulation in leaf at different locations were quite high compared with Reb-A (Table 5). Irrespective of nutritional treatments, overall performance in terms of secondary metabolites accumulation was better under CSIR-IHBT conditions compared with rest of the locations. In contrast to total SGs, the Reb-A content under PAU condition was similar to CSIR-IHBT. The least performance was found under RHRS conditions.

\section{Principal component analysis}

Principal component analysis (PCA) was carried out using the set of 10 variables for CSIR-IHBT and 6 variables for RHRS and PAU conditions. The data presented in the
Figure 4a-f revealed that the first two components, $\mathrm{PC}_{1}$ and $\mathrm{PC}_{2}$, explained $65.51,77.43$ and $83.54 \%$ of the total variations for CSIR-IHBT, RHRS and PAU conditions, respectively. Figure 4a, c and e show the relationships among the variables in the space of the first two components $\left(\mathrm{PC}_{1}\right.$ and $\left.\mathrm{PC}_{2}\right)$, and also indicate the magnitude of variable-contribution to the principal components for the respective locations. Under CSIR-IHBT condition, except Reb-A $\left(V_{5}\right)$, all variables [(leaf yield $\left(V_{1}\right)$, stem yield $\left(V_{2}\right)$, $\mathrm{HI}\left(\mathrm{V}_{3}\right)$, stevioside $\left(\mathrm{V}_{4}\right)$, stevioside: Reb-A $\left(\mathrm{V}_{6}\right)$, total LAI $\left(V_{7}\right)$, branches at 1st harvest $\left(V_{8}\right)$, branches at 2nd harvest $\left(\mathrm{V}_{9}\right)$ and total $\mathrm{Chl}\left(\mathrm{V}_{10}\right)$ ] are located in the positive coordinate of $\mathrm{PC}_{1}$. However, the loading values (correlation coefficient) of $\mathrm{V}_{1}, \mathrm{~V}_{2}, \mathrm{~V}_{7}, \mathrm{~V}_{8}$ and $\mathrm{V}_{9}$ with $\mathrm{PC}_{1}$ were too high (more than 0.8). The PCA bi-plot (Figure 4b.) separated the treatment $\mathrm{T}_{17}\left(\mathrm{~N}_{3} \mathrm{P}_{2} \mathrm{~K}_{2}\right)$ by $\mathrm{PC}_{1}$ and $\mathrm{PC}_{2}$ and placed in the positive coordinate of both PCs; whereas, the first 6 treatments $\left(\mathrm{T}_{1}-\mathrm{T}_{6}\right)$ are located in the same cluster. The PCA bi-plots (Figure 4a and b) explained strong associations among the major variables for $\mathrm{T}_{17}$, and also confirming the data presented in the Tables 2 and 3. 
Table 5 Comparison of secondary metabolite profile changes as influenced by applied $\mathbf{N}, \mathrm{P}$ and $\mathrm{K}$ under different agro-climatic conditions

\begin{tabular}{|c|c|c|c|c|c|c|c|c|c|c|c|c|}
\hline \multirow[t]{2}{*}{ Treatment } & \multicolumn{3}{|c|}{ Stevioside (ST) content (\%) } & \multicolumn{3}{|c|}{ Rebaudioside -A (Rab-A) content (\%) } & \multicolumn{3}{|c|}{ ST + Reb-A content (\%) } & \multicolumn{3}{|l|}{ ST: Reb-A } \\
\hline & IHBT & RHRS & PAU & IHBT & RHRS & PAU & IHBT & RHRS & PAU & IHBT & RHRS & PAU \\
\hline \multicolumn{13}{|c|}{ Nitrogen Level } \\
\hline $\mathrm{N}_{30}$ & $9.98 \pm 0.69$ a & $5.42 \pm 0.92 \mathrm{a}$ & $7.21 \pm 0.22 \mathrm{a}$ & $3.38 \pm 0.22 \mathrm{a}$ & $2.93 \pm 0.29 a$ & $4.48 \pm 0.24 \mathrm{a}$ & $13.37 \pm 0.75 a$ & $8.35 \pm 1.11 a$ & $11.70 \pm 0.40 \mathrm{a}$ & $3.01 \pm 0.26 \mathrm{a}$ & $1.82 \pm 0.23 \mathrm{a}$ & $1.63 \pm 0.08 \mathrm{a}$ \\
\hline $\mathrm{N}_{60}$ & $12.68 \pm 0.43 b$ & $6.23 \pm 1.13 \mathrm{a}$ & $8.37 \pm 1.02 \mathrm{a}$ & $3.52 \pm 0.25 a$ & $2.37 \pm 0.43 a$ & $3.30 \pm 0.48 \mathrm{a}$ & $16.20 \pm 0.43 b$ & $8.60 \pm 0.92 \mathrm{a}$ & $11.67 \pm 0.88 \mathrm{a}$ & $3.75 \pm 0.42 \mathrm{a}$ & $3.33 \pm 0.98 \mathrm{a}$ & $3.04 \pm 0.75 b$ \\
\hline $\mathrm{N}_{90}$ & $10.73 \pm 0.69 \mathrm{ab}$ & $7.15 \pm 0.60 \mathrm{a}$ & $7.00 \pm 1.013 \mathrm{a}$ & $3.42 \pm 0.30 \mathrm{a}$ & $2.63 \pm 0.37 a$ & $3.67 \pm 0.44 \mathrm{a}$ & $14.15 \pm 0.88 \mathrm{ab}$ & $9.78 \pm 0.57 \mathrm{a}$ & $10.67 \pm 1.08 \mathrm{a}$ & $3.24 \pm 0.26 \mathrm{a}$ & $3.00 \pm 0.46 \mathrm{a}$ & $2.16 \pm 0.60$ \\
\hline \multicolumn{13}{|c|}{ Phosphorus Level } \\
\hline$P_{20}$ & $10.99 \pm 0.67 \mathrm{a}$ & $6.20 \pm 0.74 a$ & $7.51 \pm 0.41 \mathrm{a}$ & $3.46 \pm 0.19 a$ & $2.99 \pm 0.28 \mathrm{a}$ & $3.84 \pm 0.41 \mathrm{a}$ & $14.44 \pm 0.77 a$ & $9.19 \pm 0.76 \mathrm{a}$ & $11.36 \pm 0.35 a$ & $3.24 \pm 0.21 \mathrm{a}$ & $2.25 \pm 0.37 a$ & $2.41 \pm 0.55 \mathrm{a}$ \\
\hline$P_{40}$ & $11.28 \pm 0.58 \mathrm{a}$ & $6.33 \pm 0.78 a$ & $7.54 \pm 0.90 \mathrm{a}$ & $3.42 \pm 0.22 \mathrm{a}$ & $2.3 \pm 0.27 a$ & $3.79 \pm 0.31 \mathrm{a}$ & $14.70 \pm 0.62 a$ & $8.63 \pm 0.71 \mathrm{a}$ & $11.33 \pm 0.90 \mathrm{a}$ & $3.42 \pm 0.33 a$ & $3.18 \pm 0.65 a$ & $2.14 \pm 0.42 \mathrm{a}$ \\
\hline \multicolumn{13}{|c|}{ Potassium Level } \\
\hline $\mathrm{K}_{20}$ & $11.78 \pm 0.56 \mathrm{a}$ & $5.58 \pm 0.69 a$ & $7.65 \pm 0.87 a$ & $3.50 \pm 0.87 a$ & $2.60 \pm 0.31 \mathrm{a}$ & $3.27 \pm 0.59 \mathrm{a}$ & $15.28 \pm 0.62 \mathrm{a}$ & $8.19 \pm 0.72 a$ & $10.92 \pm 0.92 \mathrm{a}$ & $3.40 \pm 0.20 \mathrm{a}$ & $2.30 \pm 0.40 \mathrm{a}$ & $2.93 \pm 0.78 \mathrm{a}$ \\
\hline$K_{40}$ & $11.35 \pm 0.36 \mathrm{a}$ & $6.78 \pm 1.04 \mathrm{a}$ & $7.58 \pm 0.24 \mathrm{a}$ & $3.70 \pm 0.24 a$ & $2.57 \pm 0.41 \mathrm{a}$ & $4.37 \pm 0.18 \mathrm{a}$ & $15.05 \pm 0.43 a$ & $9.35 \pm 0.86 \mathrm{a}$ & $11.95 \pm 0.30 \mathrm{a}$ & $3.08 \pm 0.12 \mathrm{a}$ & $3.16 \pm 0.81 \mathrm{a}$ & $1.75 \pm 0.09 a$ \\
\hline$K_{60}$ & $10.27 \pm 1.10 \mathrm{a}$ & $6.43 \pm 1.035 a$ & $7.35 \pm 1.23 \mathrm{a}$ & $3.12 \pm 1.23 \mathrm{a}$ & $2.77 \pm 0.40 \mathrm{a}$ & $3.82 \pm 0.36 \mathrm{a}$ & $13.38 \pm 1.17 a$ & $9.20 \pm 1.12 \mathrm{a}$ & $11.17 \pm 1.09 a$ & $3.51 \pm 0.54 \mathrm{a}$ & $2.68 \pm 0.77 a$ & $2.14 \pm 0.63 \mathrm{a}$ \\
\hline
\end{tabular}

The data are means $\pm S E$ ( $n=6$ for nitrogen; $n=9$ phosphorus; $n=6$ for potassium). Values with the same letter are not significantly different $(P=0.05)$ in the respective factors. $N_{1}, N_{2}$ and $N_{3}$ are the level of nitrogen @ 30,60 and $90 \mathrm{~kg} \mathrm{ha}^{-1}$, respectively. $\mathrm{P}_{1}$ and $\mathrm{P}_{2}$ are the level of phosphorus $\left(\mathrm{P}_{2} \mathrm{O}_{5}\right) @ 20$ and $40 \mathrm{~kg} \mathrm{ha}^{-1}$, respectively, while $\mathrm{K}_{1}, \mathrm{~K}_{2}$ and $\mathrm{K}_{3}$ are representing the level of potassium $\left(\mathrm{K}_{2} \mathrm{O}\right) @ 20,40$ and $60 \mathrm{~kg} \mathrm{ha}^{-1}$, respectively. 

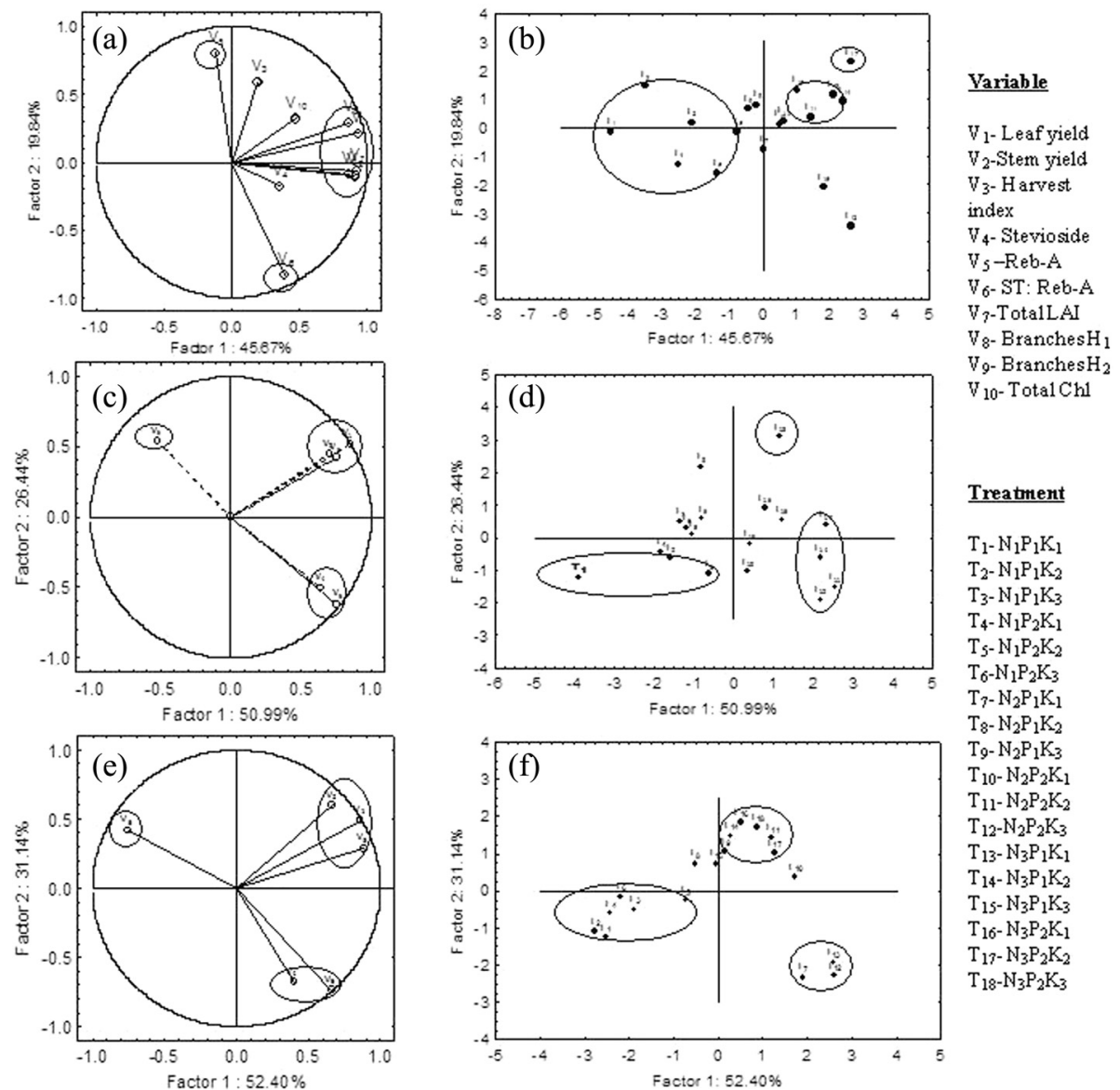

Figure 4 Bi-plot of principal components based on mean value of yield, yield attributes secondary metabolites profile and Chl data. Factor 1 and Factor 2 explain $65.51,77.43$ and $83.54 \%$ of the data variation for CSIR-IHBT, RHRS and PAU, respectively. Figure $\mathbf{a}, \mathbf{c}$ and $\mathbf{e}$ are the variable vector distributions; Figure $\mathbf{b}, \mathbf{d}$ and $\mathbf{f}$ are the case distributions (treatment combinations). The loading values of variables are presented (a, $\mathrm{c}$ and e) as vectors in the space of the PCA bi-plots. $N_{1}, N_{2}$ and $N_{3}$ are the level of nitrogen @ 30,60 and $90 \mathrm{~kg} \mathrm{ha}^{-1}$, respectively. $P_{1}$ and $P_{2}$ are the level of phosphorus @ 20 and $40 \mathrm{~kg} \mathrm{ha}^{-1}$, respectively, while $\mathrm{K}_{1}, \mathrm{~K}_{2}$ and $\mathrm{K}_{3}$ are representing the level of potassium @ 20, 40 and $60 \mathrm{~kg} \mathrm{ha}^{-1}$, respectively.

The PCA bi-plots (Figure 4c and e) show a similar pattern of variable vectors distribution for RHRS and PAU conditions. It is clear that the $\mathrm{PC}_{1}$ has positive coefficients with 5 variables $\left(\mathrm{V}_{1}, \mathrm{~V}_{2}, \mathrm{~V}_{3}, \mathrm{~V}_{4}\right.$ and $\left.\mathrm{V}_{6}\right)$ and negative coefficients with $\mathrm{V}_{5}$. The $\mathrm{V}_{1}, \mathrm{~V}_{2}, \mathrm{~V}_{3}$ and $\mathrm{V}_{6}$ have similar heavy loadings for $\mathrm{PC}_{1}$. In case-distribution-plot (Figure $4 \mathrm{~d}$ ), $\mathrm{T}_{17}$ and $\mathrm{T}_{18}$ are separated along with $\mathrm{PC}_{1}$ and $\mathrm{PC}_{2}$, respectively, from rest of the treatments under RHRS conditions. Thus, the overall PCA output indicates that $\mathrm{T}_{17}\left(\mathrm{~N}_{3} \mathrm{P}_{2} \mathrm{~K}_{2}\right)$ represents the best nutritional conditions in terms of dry leaf $\left(\mathrm{t} \mathrm{ha}^{-1}\right)$ for CSIR-IHBT and RHRS. However, under PAU condition, there was no single treatment, which was distinctly different from rest of the treatments.

\section{Nutrient (NPK) uptake}

The data presented in the Figure 5 revealed that the nutrient (NPK) uptake by stevia (above ground parts) in response to different levels of $\mathrm{N}, \mathrm{P}$ and $\mathrm{K}$ fertilizer was significant $(P \leq 0.05)$. Among the $\mathrm{N}$ levels, the application of higher dose $\left(90 \mathrm{~kg} \mathrm{~N} \mathrm{ha}^{-1}\right)$ resulted in significantly higher $\mathrm{N}\left(47.02\right.$ and $\left.59.05 \mathrm{~kg} \mathrm{ha}^{-1}\right), \mathrm{P}(11.43$ and $\left.16.74 \mathrm{~kg} \mathrm{ha}^{-1}\right)$, and $\mathrm{K}\left(75.35\right.$ and $116.1 \mathrm{~kg} \mathrm{ha}^{-1}$ ) uptake by stevia compared with lower dose $\left(30 \mathrm{~kg} \mathrm{ha}^{-1}\right)$ in 2010 and 2011. Uptake of $\mathrm{P}$ and $\mathrm{K}$ also followed a trend similar to that observation for $\mathrm{N}$, with greatest value was observed in plants, which received $90 \mathrm{~kg} \mathrm{~N} \mathrm{ha}^{-1}$ in both the years. The effect of $\mathrm{P}$ on nutrient (NPK) uptake was significant $(P \leq 0.05)$, and the maximum values were recorded with $40 \mathrm{~kg} \mathrm{P} \mathrm{ha}^{-1}$ in both the years (Figure 5). We also observed that the application of higher dose of $\mathrm{K}\left(60 \mathrm{~kg} \mathrm{ha}^{-1}\right)$ significantly $(P \leq 0.05)$ increased $\mathrm{N}$ and $\mathrm{P}$ uptake in both the years and $\mathrm{K}$ uptake in 2010 compared with lower dose $\left(30 \mathrm{~kg} \mathrm{ha}^{-1}\right)$.

\section{Chemical properties of soil after harvest}

The chemical properties ( $\mathrm{pH}, \mathrm{OC}, \mathrm{AN}, \mathrm{AP}$ and $\mathrm{AK})$ of the soil were not significantly $(P \geq 0.05)$ changed by the 

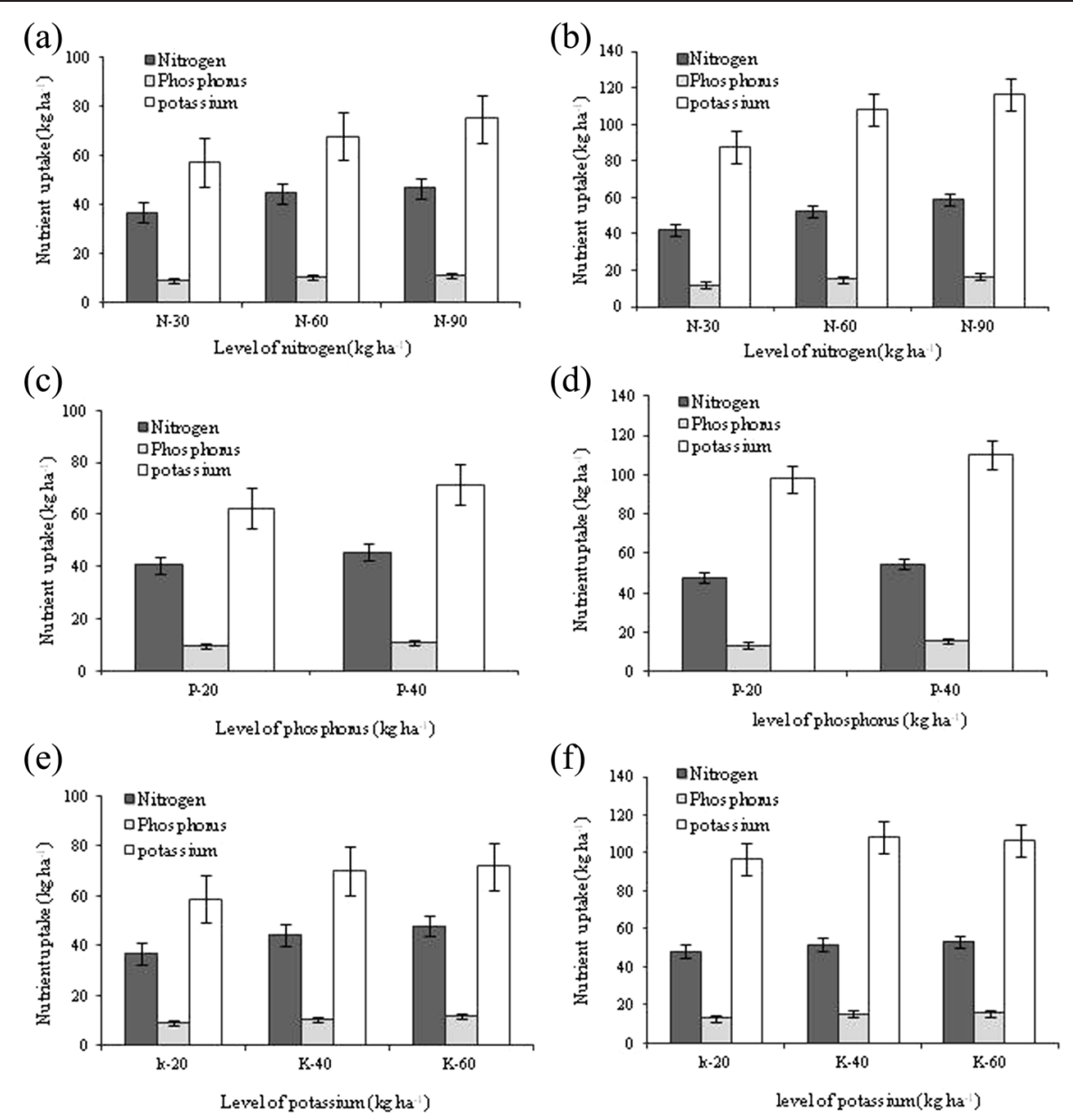

Figure 5 Relative uptake of total N, P and K by above ground biomass of stevia under varying levels of N (a, b), P (c, d) and K (e, f) application at CSIR-IHBT. Vertical bars indicate a mean standard error ( \pm ).

levels of NPK application except $\mathrm{pH}$ value in 2010 (Table 6). Significantly $(P \leq 0.05)$ lowest $\mathrm{pH}$ value $(6.26)$ was registered with $\mathrm{N}_{3}$ compared with $\mathrm{N}_{1}$ in 2010. Soil OC was not significantly $(P \geq 0.05)$ influenced by the applied $N$; however, $\mathrm{N}_{3}$ maintained the highest value (2.57 and $\left.2.20 \%\right)$, and lowest (2.40 and $2.02 \%$ ) value was observed with $\mathrm{N}_{2}$ in both the years. In this study, the change of AN, AP and AK content in the soil was not considerable; however, maximum AN (222.83 and $327.88 \mathrm{~kg} \mathrm{ha}^{-1}$ ) was recorded with $\mathrm{N}_{1}$. On the other hand, $\mathrm{K}$ content in the soil was marginally improved by the moderate level of $\mathrm{K}\left(40 \mathrm{~kg} \mathrm{ha}^{-1}\right)$ compared with lower $\left(20 \mathrm{~kg} \mathrm{ha}^{-1}\right)$ and higher $\left(60 \mathrm{~kg} \mathrm{ha}^{-1}\right)$ dose.

\section{Discussion}

Branches and LAI, the main yield-attributes of stevia, were significantly $(P \leq 0.05)$ higher, particularly at 1 st harvesting stage, with higher dose of nitrogen. Fagerstrom and Lohm [34] and Marschner [35] reported that N stimulated the leaf production probably due to the increasing production of cytokinin in root tips and their eventual export to the shoot. On one hand, $\mathrm{NO}_{3}^{-}$promotes lateral roots elongation through the accumulation of auxin [36]. On the other hand, $\mathrm{NO}_{3}^{-}$induces cytokinin production [37,38], which is necessary to encourage lateral root development in response to a systemic-N signaling [39]. It has also been reported that the foliar application of different $\mathrm{NO}_{3}^{-}$and $\mathrm{NH}_{4}^{+}$salts $\left[\left(\mathrm{KNO}_{3}, \mathrm{Ca}\left(\mathrm{NO}_{3}\right)_{2}\right.\right.$ and $\left.\left.\left(\mathrm{NH}_{4}\right)_{6} \mathrm{Mo}_{7} \mathrm{O}_{24}\right)\right]$ increased the number of branches and LAI compared with water spray control [3]. In the present study, the increase in LAI in response to increase in P level was probably due to enhanced availability of $\mathrm{P}$, which improved leaf expansion and photosynthesis per unit leaf area. Maximum LAI was observed with high and moderate levels of $\mathrm{K}$ in 2010 and 2011, respectively. This result might be attributed to a longer leaf lifespan, which ultimately enhanced LAI. A positive effect of $\mathrm{K}$ fertilization on the leaf lifespan of field-grown almond tree was also reported [40].

In this study, the dry leaf yield $\left(\mathrm{t} \mathrm{ha}^{-1}\right)$ of stevia was increased by increasing the $\mathrm{N}$ level at all three locations. These results may be due to the fact that higher dose of $\mathrm{N}$ 
Table 6 Effect of applied $\mathrm{N}$ P and $\mathrm{K}$ on soil pH, organic carbon (OC), available nitrogen (AN), available phosphorus (AP) and available potassium (AK) at CSIR-IHBT

\begin{tabular}{|c|c|c|c|c|c|c|c|c|c|c|}
\hline \multirow[t]{2}{*}{ Treatment } & \multicolumn{2}{|l|}{$\mathrm{pH}$} & \multicolumn{2}{|c|}{ OC (\%) } & \multicolumn{2}{|c|}{ AN $\left(\mathrm{kg} \mathrm{ha}^{-1}\right)$} & \multicolumn{2}{|c|}{ AP $\left(\mathrm{kg} \mathrm{ha}^{-1}\right)$} & \multicolumn{2}{|c|}{ AK $\left(\mathrm{kg} \mathrm{ha}^{-1}\right)$} \\
\hline & 2010 & 2011 & 2010 & 2011 & 2010 & 2011 & 2010 & 2011 & 2010 & 2011 \\
\hline \multicolumn{11}{|l|}{ Nitrogen Level } \\
\hline $\mathrm{N}_{30}$ & 6.59 & 5.88 & 2.41 & 2.15 & 222.83 & 327.88 & 62.51 & 59.42 & 549.55 & 486.38 \\
\hline $\mathrm{N}_{60}$ & 6.35 & 5.85 & 2.40 & 2.02 & 212.72 & 319.35 & 67.65 & 55.12 & 557.75 & 494.15 \\
\hline $\mathrm{N}_{90}$ & 6.26 & 5.83 & 2.57 & 2.20 & 205.06 & 310.11 & 64.67 & 66.34 & 544.66 & 504.70 \\
\hline $\operatorname{SEm}( \pm)$ & 0.08 & 0.04 & 0.12 & 0.10 & 7.87 & 12.08 & 4.33 & 7.42 & 10.02 & 19.85 \\
\hline$C D(P=0.05)$ & 0.22 & NS & NS & NS & NS & NS & NS & NS & NS & NS \\
\hline \multicolumn{11}{|l|}{ Phosphorus Level } \\
\hline$P_{20}$ & 6.42 & 5.86 & 2.5 & 2.07 & 210.57 & 326.84 & 65.08 & 61.33 & 540.33 & 495.35 \\
\hline$P_{40}$ & 6.39 & 5.85 & 2.43 & 2.18 & 216.50 & 311.39 & 64.81 & 59.26 & 560.98 & 494.81 \\
\hline $\operatorname{SEm}( \pm)$ & 0.06 & 0.03 & 0.10 & 0.08 & 6.43 & 9.86 & 3.53 & 6.06 & 8.18 & 16.20 \\
\hline$C D(P=0.05)$ & NS & NS & NS & NS & NS & NS & NS & NS & NS & NS \\
\hline \multicolumn{11}{|l|}{ Potassium Level } \\
\hline $\mathrm{K}_{20}$ & 6.47 & 5.86 & 2.56 & 2.01 & 215.69 & 327.01 & 67.13 & 52.07 & 548.45 & 478.68 \\
\hline $\mathrm{K}_{40}$ & 6.42 & 5.82 & 2.37 & 2.25 & 208.89 & 314.29 & 57.99 & 67.85 & 559.35 & 503.53 \\
\hline $\mathrm{K}_{60}$ & 6.33 & 5.89 & 2.46 & 2.11 & 216.03 & 316.03 & 69.7 & 60.96 & 544.17 & 503.02 \\
\hline $\operatorname{SEm}( \pm)$ & 0.08 & 0.04 & 0.12 & 0.10 & 7.87 & 12.08 & 4.33 & 7.42 & 10.02 & 19.85 \\
\hline$C D(P=0.05)$ & NS & NS & NS & NS & NS & NS & NS & NS & NS & NS \\
\hline \multicolumn{11}{|l|}{ Interaction effect } \\
\hline$C D$ of $N \times P$ & NS & NS & NS & NS & NS & NS & NS & NS & NS & NS \\
\hline $\mathrm{CD}$ of $\mathrm{N} \times \mathrm{K}$ & NS & NS & NS & NS & NS & NS & NS & NS & NS & NS \\
\hline$C D$ of $P \times K$ & 0.31 & NS & NS & 0.47 & NS & 49.08 & NS & NS & NS & NS \\
\hline $\mathrm{CD}$ of $\mathrm{N} \times \mathrm{P} \times \mathrm{K}$ & NS & NS & NS & NS & NS & NS & NS & NS & NS & NS \\
\hline
\end{tabular}

$N_{1}, N_{2}$ and $N_{3}$ are the level of nitrogen @ 30,60 and 90 kg ha ${ }^{-1}$, respectively. $P_{1}$ and $P_{2}$ are the level of phosphorus $\left(P_{2} \mathrm{O}_{5}\right) @ 20$ and 40 kg ha ${ }^{-1}$, respectively, while $\mathrm{K}_{1}, \mathrm{~K}_{2}$ and $\mathrm{K}_{3}$ are representing the level of potassium $\left(\mathrm{K}_{2} \mathrm{O}\right) @ 20,40$ and $60 \mathrm{~kg} \mathrm{ha}^{-1}$, respectively.

increased the availability of $\mathrm{N}$ in soil, and subsequently induced cytokinin synthesis in root tips and maintained desirable cytokinin and auxin ratio. Therefore, the maximum leaf yield was obtained with higher dose of $\mathrm{N}$ as a result of higher LAI. Ioio et al. [41] reported that root cell division and differentiation are controlled by the cytokinin and auxin ratio. Moreover, during embryogenesis, cytokinin and auxin control the events of major cell specification [42]. It has also been reported that limited supply of $\mathrm{N}$ decreased root growth, inhibited lateral root initiation, increased the $\mathrm{C} / \mathrm{N}$ ratio within the plant, decreased photosynthesis, and early leaf senescence [43-47].

In the present study, the application of the higher dose of $\mathrm{P}$ ( $40 \mathrm{~kg} \mathrm{P}_{2} \mathrm{O}_{5} \mathrm{ha}^{-1}$ ) leads to considerably higher dry leaf yield compared with the lower dose of $\mathrm{P}\left(20 \mathrm{~kg} \mathrm{P} \mathrm{P}_{5}\right.$ ha $\left.{ }^{-1}\right)$. These results may be due to the fact that $\mathrm{P}$ is an essential component of key molecules such as nucleic acids, phospholipids, and ATP [20], which are necessary for photosynthesis, energy transfer, carbohydrate and protein synthesis, and lipid metabolism [48]. The moderate level of $\mathrm{K}$ was most effective in terms of dry leaf yield of stevia at all three locations. The results are in accordance with the findings of Laclaun et al. [49].

From the present study it is confirmed that the growth and dry matter accumulation of stevia are markedly governed by the prevailing environmental conditions during plantation and vegetative growth phases. The plants, grown under CSIR-IHBT conditions, produced maximum dry leaf and stem yield, while least performance was found under PAU condition. These results could be due to the fact that environmental conditions, particularly temperature was not favourable during plantation and vegetative growth phases at PAU. Sometime the maximum temperature at PAU reached more than $42^{\circ} \mathrm{C}$ during plant establishment and vegetative growth stages (Figure 1 ). The extremely high temperature and corresponding lower $\mathrm{RH}$ could have reduced photosynthetic activities, and lowered the yield at PAU.

The total Chl was significantly $(\mathrm{P} \leq 0.05)$ increased with higher level of $\mathrm{N}$. These results may be due to the fact that $\mathrm{N}$ is an essential component of green pigment of plants [50]. On the other hand, the $\mathrm{Chl} a / b$ ratio was lowest with 
higher dose of N. Hikosaka and Terashima [51] reported that Chl $a / b$ ratio was decreased with the increase in $\mathrm{N}$ availability at a defined light intensity.

In this study, applied $\mathrm{N}, \mathrm{P}$ and $\mathrm{K}$ had little effect in altering the concentration of $\mathrm{N}, \mathrm{P}$ and $\mathrm{K}$ in plant body. This result was probably due to the dilution affect of nutrient content. The uptake of $\mathrm{N}, \mathrm{P}$ and $\mathrm{K}\left(\mathrm{kg} \mathrm{ha}^{-1}\right)$ by above ground biomass of stevia was increased progressively with the increase of $\mathrm{N}$ level from 30 to $90 \mathrm{~kg} \mathrm{ha}^{-1}$. The better availability of $\mathrm{N}$ encourages root proliferation through auxin and cytokinin synthesis [36-38], resulting in removing more nutrients from large area and greater soil depth. The increased biomass production coupled with moderate concentration of $\mathrm{N}, \mathrm{P}$ and $\mathrm{K}$ in leaf and stem also may be the cause of higher uptake of N, P and $\mathrm{K}$ under higher dose of $\mathrm{N}$. Though the concentrations of $P$ in leaf and stem were not changed significantly $(P \geq$ $0.05)$, the uptake of $P$ was increased significantly $(P \leq$ $0.05)$ with higher dose of $P$. This increase was generally caused by higher dry leaf and stem yield. Mollier and Pellerin [52] reported that root growth of maize (Zea mays L.) was strongly reduced after a few days of P starvation, and the emergence of new axile roots and elongation of first-order lateral roots were also radically reduced. It has also been reported that $\mathrm{P}$ deficiency reduced absolute root growth of rice (Oryza sativa L.), and this reduction was more pronounced in genotypes with a low tolerance to P deficiency [53].

Stevioside accumulation in leaf was significantly improved by the moderate level of $\mathrm{N}$ under CSIR-IHBT conditions. This result might be attributed to synergistic effect with other essential nutrients, which improved the biochemical activities for increasing stevioside. The higher stevioside content in leaf with moderate level of $\mathrm{N}$ might be attributed to the desired level of photosynthetic pigments. Ladygin et al. [54] reported that accumulation of steviol glycosides in cells of stevia in vivo and in vitro was related to the extent of the development of the membrane system of chloroplasts and the content of photosynthetic pigments. The variation in stevioside accumulation in leaves due to location variation was quite high compared with Reb-A. Thus the results suggest that accumulation of stevioside is influenced by environmental and soil conditions. It has been reported that stevioside levels vary depending on the growing conditions and genotype [55]. In our study, Reb-A content did not much vary due to site variation, which suggested that Reb-A synthesis is governed by others factors not by growing conditions. Brandle [56] suggests that the presence of Reb-A is controlled by a single gene, but there may be an additive multiallelic locus for controlling the actual proportions. The functional role of the recombinant UGTSr in the synthesis of Reb-A was also ascertained by Madhav et al. [57].
The soil $\mathrm{pH}$ tended to decline with the increasing level of NPK fertilizer, which is in accordance with the finding of Dong et al. [58]. Thus, this result suggested that chemical fertilizer could increase soil acidity to some extent. Applied N PK fertilizer did not significantly alter the soil OC, AN, AP and AK. However, soil OC was increased to some extent with higher dose of $\mathrm{N}$. These results may be due to the fact that higher level of $\mathrm{N}$ ensures the large and constant presence of active microorganism and the regular dynamic of biomass carbon [59]. In contrast, AN was declined with higher dose of applied $\mathrm{N}$ probably due to higher removal of $\mathrm{N}$ through aboveground biomass and high $\mathrm{C} / \mathrm{N}$ ratio.

\section{Conclusions}

The results, obtained in the present study, suggest that the dry leaf yield and biosynthesis of secondary metabolites of stevia are strongly controlled by the exogenous supply of plant nutrition, soil properties and climatic conditions of the growing region. Therefore, it can be concluded that higher dose of $\mathrm{N}$ and moderate level of $\mathrm{K}$ are helpful to increase the dry leaf yield under CSIR-IHBT and RHRS conditions. Furthermore, the sub-temperate climatic conditions of CSIR-IHBT are more favourable compared with other two locations in terms of leaf yield and secondary metabolites accumulation particularly when plant was grown during 13-15 MSW. These observations indicate that stevia plants are not able to cope with high temperatures coupled with low humidity during initial vegetative growth stages. It can also be concluded that dry leaf yield and stevioside accumulation are governed by environment and agronomic practices. However, Reb-A is controlled by others factors like genetic and enzymatic [56,57]. The changes in leaf yield and accumulation patterns of stevioside observed in response to different environmental conditions and nutritional variations provide leads for developing the strategies to increase the productivity of the stevia under different agro-climatic conditions. Thus, leaf yield and secondary metabolite profiles of the stevia can be improved through the selection of appropriate growing locations and proper nutrient management. However, further studies are required to standardize the planting date for different regions and to understand the relationship between plant nutrient and enzyme activities which are responsible for secondary metabolites synthesis.

\section{Competing interests}

The authors declare that they have no competing interests.

\section{Authors' contributions}

PKP- experiment designed and executed, data collection, data processing, Chemical analyses, Statistical analysis, manuscript writing. VG, RK, BSG, DS and GC- data collection, data processing. MM and RP- Soil and Plant sample analyses, literature search. VP- Steviol glycosides analyses. BS- Guided and executed for Steviol glycosides analysis. RDS- Planning of experiment \& Manuscript Editing. PSA- Planning of experiment and overall supervision of the experiment. All authors read and approved the final manuscript. 


\section{Acknowledgements}

The authors are grateful to Mr. Kuldeep Singh Gill for field management. The authors acknowledge the Council of Scientific and Industrial Research (CSIR), Government of India, for financial support.

\begin{abstract}
Author details
${ }^{1}$ Natural Product Chemistry and Process Development Division, Council of Scientific and Industrial Research-Institute of Himalayan Bioresource Technology (CSIR-IHBT), Post Box No. 6, Palampur 176 061HP, India. ${ }^{2}$ Department of Agronomy, Punjab Agricultural University, Ludhiana 141004 India. ${ }^{3}$ Regional Horticultural Research Station (RHRS), Dr YS Parmar University of Horticulture and Forestry, Jachh, Himachal Pradesh, India. ${ }^{4}$ Division of Hill Area Tea Science, CSIR-IHBT, Post Box No. 6, Palampur 176 061, India. ${ }^{5}$ Division Biodiversity, CSIR-IHBT, Post Box No. 6, Palampur 176061 India. ${ }^{6}$ Division of Biotechnology, CSIR-IHBT, Post Box No. 6, Palampur 176 061, India.
\end{abstract}

Received: 18 September 2014 Accepted: 13 February 2015 Published online: 27 February 2015

\section{References}

1. Brandle JE, Starratt AN, Gijzen M. Stevia rebaudiana: its agricultural, biological, and chemical properties. Can J Plant Sci. 1998;78:527-36.

2. Ramesh K, Singh V, Megeji NW. Cultivation of stevia [Stevia rebaudiana (Bert.) Bertoni]: a comprehensive review. Advs Agron. 2006;89:137-77.

3. Pal PK, Prasad R, Pathania V. Effect of decapitation and nutrient applications on shoot branching, yield, and accumulation of secondary metabolites in leaves of Stevia rebaudiana Bertoni. J Plant Physiol. 2013;170:1526-35.

4. Kinghorn AD, Soejarto DD. Sweetening agents of plant origin. Crit Rev Plant Sci. 1986:4:79-120.

5. Bondarev NI, Sukhanova MA, Reshetnyak OV, Nosov AM. Steviol glycoside content in different organs of Stevia rebaudiana and its dynamics during ontogeny. Biol Plantarum. 2003;47:261-4.

6. Crammer B, Ikan R. Sweet glycosides from the Stevia plant. Chem Br. 1986;22:915-6.

7. Kinghorn AD, Soejarto DD. Stevioside. In: O'Brien Nabors L, Gelardi RC, editors. Alternative Sweeteners. New York: Marcel Dekker, Inc; 1991. p. 157-71.

8. Tanaka O. Improvement of taste of natural sweeteners. Pure Appl Chem. 1997;69:675-83.

9. EFSA (European Food Safety Authority). Panel on food additives and nutrient sources (ans): scientific opinion on safety of steviol glycosides for the proposed uses as a food additive. EFSA J. 2010;8(4):1537.

10. Tavarini S, Angelini LG. Stevia rebaudiana Bertoni as a source of bioactive compounds: the effect of harvest time, experimental site and crop age on steviol glycoside content and antioxidant properties. J Sci Food Agri. 2013;93:2121-9.

11. JECFA (Joint FAO/WHO Expert Committee on Food Additives). Safety evaluation of certain food additives, Prepared by the 69th meeting of the Joint FAO/WHO Expert Committee on Food Additives. WHO Food Additives Series No. 66. 2009. p. 183-220.

12. FSANZ: Final assessment report. A540 Steviol glycosides as intense sweeteners, Food Standards Australia New Zealand. 2008.

13. Metivier J, Viana AM. The effect of long and short day length upon the growth of whole plants and the level of soluble proteins, sugars and stevioside in leaves of Stevia rebaudiana Bert. J Exp Bot. 1979;30:1211-22.

14. Ceunen S, Geuns JMC. Influence of photoperiodism on the spatio-temporal accumulation of steviol glycosides in Stevia rebaudiana (Bertoni). Plant Sci. 2013;198:72-82.

15. Mizukami H, Shiba K, Satoshi I, Ohashi H. Effect of temperature on growth and stevioside formation of Stevia rebaudiana Bertoni. Shoyakugaku Zasshi. 1983:37:175-9.

16. Utumi MM, Monnerat PH, Pereira PRG, Fontes PCR, Godinho VPC. Macronutrient deficiencies in Stevia: visual symptoms and effects on growth, chemical composition and stevioside production. Pesqui Agropecu Bras. 1999;34:1039-43.

17. Geuns JMC. Molecules of interest stevioside. Phytochemistry. 2003;64:913-21.

18. Crawford N, Forde B. Molecular and developmental biology of inorganic nitrogen nutrition. In: Meyerowitz E, Somerville C, editors. Arabidopsis. Rockville, MD: American Society of Plant Biologists; 2002. p. 1-25.
19. Peng M, Hannam C, Gu H, Bi YM, Rothstein SJ. A mutation in NLA, which encodes a RING-type ubiquitin ligase, disrupts the adaptability of Arabidopsis to nitrogen limitation. Plant J. 2007:50:320-37.

20. Schachtman DP, Reid RJ, Ayling SM. Phosphorus uptake by plants: from soil to cell. Plant Physiol. 1998;116:447-53.

21. Clarkson DT, Hanson JB. The mineral nutrition of higher plants. Annu Rev Plant Physiol. 1980;31:239-98.

22. Kang KH, Lee FW. Physio-ecological studies on Stevia (Stevia rebaudiana Bertoni). Korean J Crop Sci. 1981;26:69-89.

23. Ceunen S, Werbrouck S, Geuns JMC. Stimulation of steviol glycoside accumulation in Stevia rebaudiana by red LED light. J Plant Physiol. 2012;169:749-52.

24. Sharma VK, Kumar A. Characterization and classification of the soils of upper Maul khad catchment in wet temperate zone of Himachal Pradesh. Agropedology. 2003;13:39-49.

25. Sidhu GS, Rana KPC, Sehgal J, Velayutham M. Soils of Himachal Pradesh: their kinds, distribution, characterization, and interpretations for optimising land use, NBSS Publ. 57, National Bureau of Soil Survey \& Land Use Planning, Indian Council of Agricultural Research. Nagpur, India. 1997.

26. Palaniappan SP, Sivaraman K. Cropping Systems in the Tropics (Principles and Management). New Delhi: New Age International (P) Ltd; 2006.

27. Arnon DI. Copper enzymes in isolated chloroplasts: polyphenoloxidase in Beta vulgaris. Plant Physiol. 1949;24:1-15.

28. Sahrawat KL, Ravi Kumar G, Murthy KVS. Sulphuric acid-Selenium digestion for multi element analysis in a single plant digest. Commun Soil Sci Plant Anal. 2002;33:3757-65.

29. Prasad R, Shivay YS, Kumar D, Sharma SN. Learning by doing exercise in soil fertility-a practical manual for soil fertility, Division of agronomy. New Delhi: |ARI; 2006.

30. Nelson DW, Sommers LE. Total carbon and organic carbon. In: Page AL, Miller RH, Keeney DR, editors. Methods of Soil Analysis. Madison, W.I: American Society of Agronomy Inc; 1982. p. 539-79.

31. Subbiah BV, Asija GL. A rapid procedure for the determination of available nitrogen in soils. Curr Sci. 1956;25:259-60.

32. Bray RH, Kurtz LT. Determination of total, organic and available forms of phosphorus in soils. Soil Sci. 1945;59:39-45.

33. Mehlich A. Mehlich-3 soil test extractant: a modification of Mehlich-2 extractant. Commun Soil Sci Plant Anal. 1984;15(12):1409-16.

34. Fagerstrom T, Lohm U. Growth in Scats pine (Pinus silvestris L.). Oecologia. 1977;26:305-15.

35. Marschner H. General introduction to the mineral nutrition of plants. In: Inorganic Plant Nutrition, Encyclopedia of Plant Physiol, vol. 15A. New York: New Series Springer-Verlag; 1983. p. 5-60.

36. Krouk G, Lacombe B, Bielach A, Perrine-Walker F, Malinska K, Mounier E, et al. Nitrate-regulated auxin transport by NRT1.1 defines a mechanism for nutrient sensing in plants. Dev Cell. 2010;18:927-37.

37. Sakakibara H, Takei K, Hirose N. Interactions between nitrogen and cytokinin in the regulation of metabolism and development. Trends Plant Sci. 2006;11:440-8

38. Takei K, Sakakibara H, Taniguchi M, Sugiyama T. Nitrogen-dependent accumulation of cytokinins in root and the translocation to leaf: Implication of cytokinin species that induces gene expression of maize response regulator. Plant Cell Physiol. 2001;42:85-93.

39. Ruffel S, Krouk G, Ristova D, Shasha D, Birnbaum KD, Coruzzi GM. Nitrogen economics of root foraging: transitive closure of the nitrate-cytokinin relay and distinct systemic signaling for N supply vs. demand. Proc Natl Acad Sci U S A. 2011;108(45):18524-9.

40. Basile B, Reidel EJ, Weinbaum SA, DeJong TM. Leaf potassium concentration, $\mathrm{CO}_{2}$ exchange and light interception in almond trees (Prunus dulcis (Mill) D.A. Webb). Sci Hortic-Amsterdam. 2003;98:185-94.

41. Ioio RD, Nakamura K, Moubayidin L, Perilli S, Taniguchi M, Morita MT, et al. A genetic framework for the control of cell division and differentiation in the root meristem. Science. 2008;332:380-1384.

42. Muller B, Sheen J. Cytokinin and auxin interactions in root stem-cell specification during early embryogenesis. Nature. 2008;453:1094-8.

43. Malamy JE, Ryan KS. Environmental regulation of lateral root initiation in Arabidopsis. Plant Physiol. 2001:127:899-909.

44. Martina A, Leeb J, Kicheyc T, Gerentesd D, Zivye M, Tatoutd C, et al. Two cytosolic glutamine synthetase isoforms of maize are specifically involved in the control of grain production. Plant Cell. 2006;18:3252-74. 
45. Malamy JE. The putative high-affinity nitrate transporter NRT2.1 represses lateral root initiation in response to nutritional cues. Proc Natl Acad Sci U S A. 2005;102:13693-8.

46. Wingler A, Purdy S, MacLean JA, Pourtau N. The role of sugars in integrating environmental signals during the regulation of leaf senescence. J Exp Bot. 2006;57:391-9.

47. Zhang Q. Strategies for developing green super rice. Proc Natl Acad Sci U S A. 2007:104:16402-9.

48. Rhykerd CL, Overdahl CJ. Nutrition and fertilizer use. In: Hanson CH, editor. Alfalfa Science and Technology, vol. 15. Madison, Wl: Agronomy Monograph, American Society of Agronomy; 1982. p. 437-68.

49. Laclaun J-P, Almeida JCR, Gonçalves JLM, Saint-Andre L, Ventura M, Ranger $J$, et al. Influence of nitrogen and potassium fertilization on leaf lifespan and allocation of above-ground growth in Eucalyptus plantations. Tree Physiol. 2009:29:111-24.

50. Lawlor DW. Carbon and nitrogen assimilation in relation to yield: mechanisms are the key to understanding production systems. J Exp Bot. 2002:53:773-87.

51. Hikosaka K, Terashima I. A model of the acclimation of photosynthesis in the leaves of $C_{3}$ plants to sun and shade with respect to nitrogen use. Plant Cell Environ. 1995;18:605-18.

52. Mollier A, Pellerin S. Maize root system growth and development as influenced by phosphorus deficiency. J Exp Bot. 1999;50:487-97.

53. Wissuwa M. Combining a modelling with a genetic approach in establishing associations between genetic and physiological effects in relation to phosphorus uptake. Plant Soil. 2005;269:57-68.

54. Ladygin VG, Bondarev NI, Semenova GA, Smolov AA, Reshetnyak OV, Nosov AM. Chloroplast ultrastructure, photosynthetic apparatus activities and production of steviol glycosides in Stevia rebaudiana in vivo and in vitro. Biol Plantarum. 2008;52(1):9-16.

55. Staratt AN, Kirby CW, Pocs Rand Brandle JE, Rebaudioside F. A diterpene glycoside from Stevia rebaudiana. Phytochemistry. 2002;59:367-70.

56. Brandle J. Genetic control of rebaudioside A and C concentration in leaves of the sweet herb, Stevia rebaudiana. Can J Plant Sci. 1999;79(1):85-91.

57. Madhav H, Bhasker S, Chinnamma M. Functional and structural variation of uridine diphosphate glycosyltransferase (UGT) gene of Stevia rebaudianaUGTSr involved in the synthesis of rebaudioside A. Plant Physiol Biochem. 2013;63:245-53.

58. Dong W, Zhang X, Wang H, Dai X, Sun X, Qiu W, et al. Effect of different fertilizer application on the soil fertility of paddy soils in red soil region of Southern China. PLoS One. 2012;9(7):e44504.

59. Nardi S, Morari F, Berti A, Tosoni M, Giardini L. Soil organic matter properties after 40 years of different use of organic and mineral fertilisers. Eur J Agron. 2004:21:357-67.

\section{Submit your next manuscript to BioMed Central and take full advantage of:}

- Convenient online submission

- Thorough peer review

- No space constraints or color figure charges

- Immediate publication on acceptance

- Inclusion in PubMed, CAS, Scopus and Google Scholar

- Research which is freely available for redistribution 